US Army Corps

of Engineers ${ }_{\circledast}$

Engineer Research and

Development Center

Gridded Surface Subsurface Hydrologic Analysis Modeling for Analysis of Flood Design Features at the Picayune Strand Restoration Project

Charles W. Downer, Jaime A. Graulau-Santiago, Brian E. Skahill,

August 2016

David M. Weston, Nawa Pradhan, and Aaron R. Byrd 
The U.S. Army Engineer Research and Development Center (ERDC) solves the nation's toughest engineering and environmental challenges. ERDC develops innovative solutions in civil and military engineering, geospatial sciences, water resources, and environmental sciences for the Army, the Department of Defense, civilian agencies, and our nation's public good. Find out more at www.erdc.usace.army.mil.

To search for other technical reports published by ERDC, visit the ERDC online library at http://acwc.sdp.sirsi.net/client/default. 


\section{Gridded Surface Subsurface Hydrologic Analysis Modeling for Analysis of Flood Design Features at the Picayune Strand Restoration Project}

Charles W. Downer, Brian E. Skahill, Nawa Pradhan, and Aaron R. Byrd

Coastal and Hydraulics Laboratory

U.S. Army Engineer Research and Development Center

3909 Halls Ferry Road

Vicksburg, MS 39180-6199

Jaime A. Graulau-Santiago and David M. Weston

Hydraulics and Hydrology Branch

U.S. Army Corps of Engineers

Jacksonville District

701 San Marcus Blvd

Jacksonville, FL 32207

Final report

Approved for public release; distribution is unlimited.

Prepared for U.S. Army Corps of Engineers, Jacksonville District

701 San Marcus Blvd

Jacksonville, FL 32207

Under Project Number 454633, "Picayune Strand Restoration Project” 


\section{Abstract}

The Picayune Strand Restoration Project is one of many components of the Comprehensive Everglades Restoration Project (CERP) intended to restore nearly 700 hectares of a failed residential development in southwestern Collier County, FL, to its predevelopment wetland conditions. A detailed analysis was performed to derive a restoration plan that will achieve this goal. As required by the Water Resources Development Act (WRDA) 2000, the U.S. Army Corps of Engineers (USACE) is required to ensure that no component of CERP results in an effective taking of land by adversely impacting the level of flood protection of adjacent landowners. To ensure the current level of flood protection is maintained, a hydrologic model was developed to assess the potential for flooding and to refine the proposed flood mitigation features. The USACE physically based Gridded Surface Subsurface Hydrologic Analysis (GSSHA) model was selected for this effort. The GSSHA model simulates fully coupled rainfall distribution, extraction, retention, overland flow, and one-dimensional channel flow. Models of varying resolution were developed from existing and proposed design data and were initially populated with parameter values from a previous hydrodynamic modeling effort. Parameters were then tuned to observed stage and flow data using the Secant Levenberg-Marquardt method, a nonlinear least squares minimization computer-based local search method. The calibrated model is capable of reproducing canal flows, canal stages, and overland stages with very high Nash Sutcliffe Forecast Efficiencies, generally 0.9 or higher. Subsequent uncertainty analysis allowed water stages to be estimated with $95 \%$ certainty. Modeling and uncertainty analysis results allowed for refinement of the proposed flood mitigation features. The hydrologic models and analysis demonstrated that some of the features in the original plan were either unnecessary or overdesigned and could be modified or eliminated, resulting in $\$ 40 \mathrm{M}$ in flood control feature construction cost savings.

DISCLAIMER: The contents of this report are not to be used for advertising, publication, or promotional purposes. Citation of trade names does not constitute an official endorsement or approval of the use of such commercial products. All product names and trademarks cited are the property of their respective owners. The findings of this report are not to be construed as an official Department of the Army position unless so designated by other authorized documents. 


\section{Contents}

Abstract................................................................................................................................... ii

Figures and Tables.................................................................................................................

Preface ...............................................................................................................................................vi

Unit Conversion Factors.......................................................................................................vii

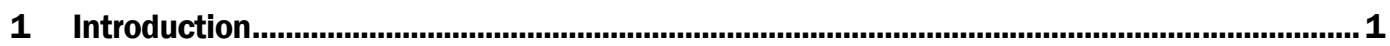

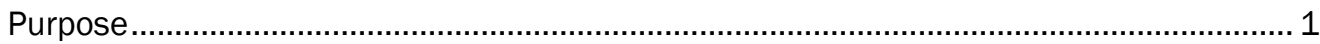

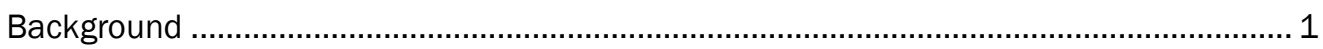

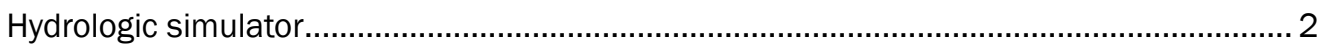

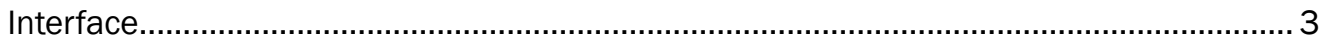

2 Preferred Restoration Alternative .................................................................................. 5

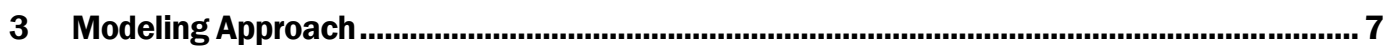

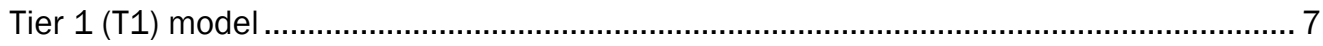

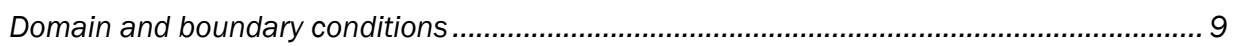

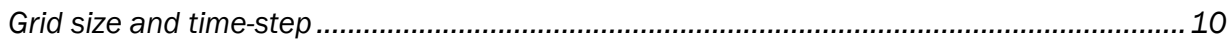

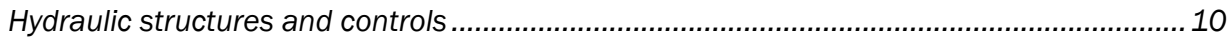

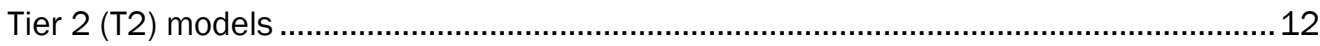

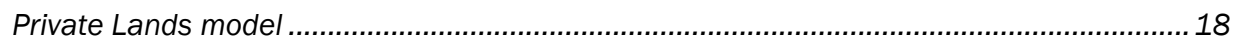

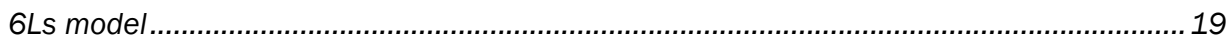

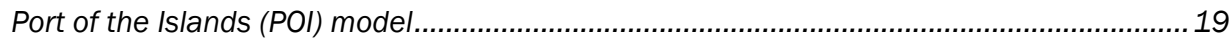

4 Gridded Surface Subsurface Hydrologic Analysis (GSSHA) Model Enhancements for Picayune Strand Restoration Project (PSRP)................................................................21

5 PSRP Model Calibration ...................................................................................................23

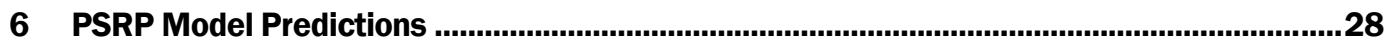

7 Maximum Flood Levels and Implications to the Protection Features Design .....................35

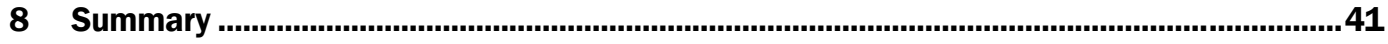

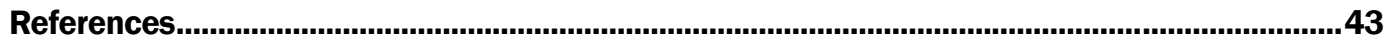

Report Documentation Page 


\section{Figures and Tables}

\section{Figures}

Figure 1. Preferred alternative.

Figure 2. T1 and T2 model domains and existing (C1) features. ....................................................... 8

Figure 3. T 1 and T 2 model domains and proposed (C2) model features. ...................................... 9

Figure 4. T1C1 Model domain for the Private Lands. .......................................................................... 13

Figure 5. T2C2 model domain for the Private Lands .................................................................... 14

Figure 6. T2C1 domain and features for the 6Ls.................................................................... 15

Figure 7. T2C2 domain and features for the 6Ls. .................................................................... 16

Figure 8. T2C1 and T2C2 domain and features for the POI. .......................................................... 17

Figure 9. Discharge time series for the Miller pump system. ........................................................ 19

Figure 10. Comparison of all simulated and observed data (FU-1 flow and stage, stage values at ditch locations numbered $36,37,52$, and 55) for the calibrated T1C1 model. ............... 27

Figure 11. The T1C1 uncertainty analysis assessment points...................................................... 30

Figure 12. T2C2 Private Lands model. The black dots indicate the approximate locations where linear predictive uncertainty analyses were performed to compute the maximum simulated stage at the $95 \%$ confidence level when the model is forced with the design storm.

Figure 13. T2C2 6Ls model. The black dots indicate the approximate locations where linear predictive uncertainty analyses were performed to compute the maximum simulated stage at the 95\% confidence level when the model is forced with the design storm. Two separate analyses were performed at distinct grid cell locations in the vicinity of the southernmost black dot indicated in the figure.

Figure 14. T1C2 model. The six pink dots indicate the approximate locations where linear and nonlinear predictive uncertainty analyses were performed to compute the maximum simulated stage at the 95\% confidence level when the T1C2 model is forced with the design storm.

Figure 15. Cell-by-cell difference of maximum flood extent for the POI T2 model. 36

Figure 16. Water surface profiles along the east boundary of the developed areas in the POI T2 model.

Figure 17. Cell-by-cell difference of maximum flood extent for the Private Lands T2 model. Western extent of the protective tie-back levee system as proposed in the PIR and as recommended in this study also shown.

Figure 18. Water surface profiles along the western portion of the proposed tie-back levee system (see Figure 17 for profile locations).

Figure 19. Cell-by-cell difference of the maximum flood extent between C2 and C1 in the 6 Ls T2 model..

Figure 20. Water surface profiles along the proposed $6 \mathrm{Ls}$ protective levee. Profile starts at the northern end of the feature and ends at the intersection of the feature with U.S. Hwy 41. 


\section{Tables}

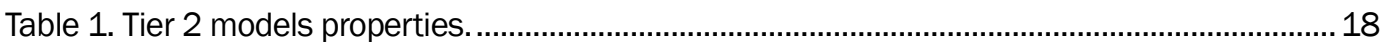

Table 2. Specified adjustable parameters for the T1C1 model, their description, and

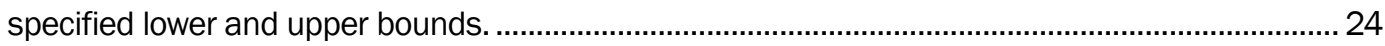

Table 3. Unique observation groups defined to calibrate T1C1 model............................................ 25

Table 4. Final estimated parameter set for the T1C1 model with uncertainty estimate....................26

Table 5. Computed model parameter sensitivities to all observations..............................................26

Table 6. Summary statistics of model to measurement misfit at the final estimated parameter set for the T1C1 model across different observation groups, including their subdivision or aggregation.

Table 7. Maximum predicted stage values, at the $95 \%$ confidence level, simulated by the T1C2 GSSHA model forced with the 5-day, 100-year design storm.

Table 8. Maximum predicted stage values, at the $95 \%$ confidence level, simulated by the T2C2 Private Lands GSSHA model forced with the 5-day, 100-year design storm. 32

Table 9. Maximum predicted stage values, at the $95 \%$ confidence level, simulated by the T2 predictive $6 \mathrm{Ls}$ model forced with the 5-day 100 -year design storm.

Table 10. Maximum predicted stage values, at the 95\% confidence level, simulated by the T1 level GSSHA predictive C2 model forced with the 5-day 100-year design storm. 


\section{Preface}

This study was conducted for the U.S. Army Corps of Engineers, Jacksonville District (SAJ), under the Comprehensive Everglades Restoration Plan (CERP), Project Number 454633, "Picayune Strand Restoration Project.” The point of contact was Dr. Jaime GraulauSantiago.

The work was performed by the Hydrologic Systems Branch (HSB), Flood and Storm Protection Division (FSPD), U.S. Army Engineer Research and Development Center, Coastal and Hydraulics Laboratory (ERDC-CHL), and the Hydraulics and Hydrology Branch, U.S. Army Corps of Engineers, Jacksonville District (USACE-SAJ-EN-WI). At the time of publication, Dr. Hwai-Ping (Pearce) Cheng was Chief of HSB; Dr. Ty Wamsley was Chief of FSPD. The Director of CHL was José E. Sánchez.

COL Bryan S. Green was the Commander of ERDC, and Dr. Jeffery P. Holland was the Director. 


\section{Unit Conversion Factors}

\begin{tabular}{|l|l|l|}
\hline Multiply & By & To Obtain \\
\hline acres & $4,046.873$ & square meters \\
\hline cubic feet & 0.02831685 & cubic meters \\
\hline feet & 0.3048 & meters \\
\hline miles (U.S. statute) & $1,609.347$ & meters \\
\hline square feet & 0.09290304 & square meters \\
\hline yards & 0.9144 & meters \\
\hline
\end{tabular}




\section{Introduction}

\section{Purpose}

The purpose of this report is to describe the model development, simulations, and results of Gridded Surface Subsurface Hydrologic Analysis (GSSHA) numerical modeling in support of level-of-service flood analysis for refinement of flood protection features proposed in the Project Implementation Report (PIR) for the Picayune Strand Restoration Project (PSRP).

\section{Background}

The PSRP will functionally restore more than 700 hectares of land in southwestern Collier County, FL, to its predevelopment condition as part of the Comprehensive Everglades Restoration Plan. Formerly known as the Southern Golden Gate Estate, the project area was intended as a residential subdivision in the 1950s. Roads and drainage canals were constructed in the 1960 s and early 1970 s for that purpose. The planned residential development did not materialize, and the roads and four canals overdrain the area. This overdrainage reduces aquifer recharge, increases freshwater discharges to downstream estuaries, promotes invasive upland vegetation, interrupts ecological connectivity, degrades habitat, and increases the frequency of wild fires. The recommended plan for the PSRP is to neutralize the existing infrastructure of the subdivision and restore its predrainage hydrology and ecological function for beneficial effects on flora and fauna in the project area and surrounding public lands. The structural features of the PSRP are the construction of a series of pump stations, levees, spreader berms, and canal plugs to impede water flowing through existing canals and redistribute it across the landscape. The U.S. Army Corps of Engineers (USACE), Jacksonville District (SAJ), in partnership with South Florida Water Management District (SFWMD), is constructing these features. Engineering support is required for hydrologic and hydraulic design of the project features. The PSRP-recommended plan was selected by the Project Delivery Team as having the greatest ecological benefit at the highest costbenefit ratio (USACE 2004). The recommended plan was selected from numerous alternative plans after years of rigorous study. 
With the plan selected, the USACE is required to maintain the existing level of flood protection to potentially affected persons/areas once the project is built. In addition, all Federal projects must also be designed with a 100-year level of flood protection. This report describes the analysis of the flood protection features only. Previous reports describe the ecological analysis and process of selecting the preferred alternative (USACE 2004).

In order to adequately determine the design parameters for the flood mitigation features, a tiered-model, design-analysis approach was applied. A large-scale, lower-resolution (Tier 1) model enabled analysis of the system at a regional level and provided the ability to estimate the response of the system in terms of flood stages and flows relative to historical and synthetic storm events. This Tier 1 ( $\mathrm{T} 1$ ) model was also used to provide boundary conditions for more detailed, high-resolution inset (Tier 2) models. The Tier 2 (T2) models enabled detailed analysis of flow and stage behavior in the vicinity of the flood mitigation features proposed in the recommended plan. The purpose of the T2 models was to determine whether adverse water stages are anticipated in and around private lands for various return intervals (i.e., the 5-, 10-, 25-, and 100-year events) and to determine if the proposed mitigation features meet the flood protection requirements. If protection features, such as levees, were found to be necessary, then the design criteria were further refined at this level, including the evaluation of risk and uncertainty.

The GSSHA spatially distributed hydrologic model (Downer et al. 2005) developed and supported at the U.S. Army Engineer Research and Development Center, Coastal and Hydraulics Laboratory (ERDC-CHL), was selected to represent the PSRP existing and proposed project conditions at the T1 and T2 scales. GSSHA provides comprehensive treatment of watershed hydrology, the capacity to substantively reflect the previously mentioned structural features, and an ability to extract state information from a coarse scale model to serve as boundary conditions for a finer scale inset model.

\section{Hydrologic simulator}

GSSHA is a physics-based, spatially explicit hydrologic model with the capacity to simulate, on a continuous basis, numerous processes relevant to the hydrologic response of a watershed system subject to meteorological forcing, including, among possible others, rainfall distribution, plant interception, surface retention, evapotranspiration, vertical infiltration, 
two-dimensional (2D) overland flow, one-dimensional (1D) channel flow, 2D groundwater flow for the unconfined aquifer system and related surface water-groundwater interaction, lake/reservoir levels, and snow accumulation and melt. Processes are treated with varying degrees of fidelity with related computational and input data requirements, allowing the modeler to choose a process solution method that is consistent with project requirements and/or to explore the potential tradeoffs between simulation accuracy and related resource requirements. Spatial data products such as digital elevation models, surveyed channel cross sections, soil classification, vegetative cover, land use, and hydro-geological characterizations of the subsurface can readily be incorporated to support model development and model process parameterization.

The GSSHA model structure is also designed to allow the modeler to reflect into the model, in a site-specific manner, various man-made alterations to the hydrologic and hydraulic watershed system including, among others, groundwater pumping, subsurface storm and tile networks, culverts, weirs, roads, and levees. Other types of external boundary conditions, such as inflow hydrographs, or the treatment of inset models whose boundary conditions are obtained from a coarser-scale GSSHA model, are also possible. The model also has the capability to actively simulate the exchange between the channel system and the floodplain. GSSHA-simulated hydrologic states can be written to files during program execution for subsequent display and evaluation. (The interested reader is directed to the GSSHA wiki (http://www.gssahwiki.com) for a complete summary of the GSSHA simulation model capabilities, including tutorial documents with related data sets, and links to obtain a current copy of the model executable, which is in the public domain and supported on multiple computing platforms.)

\section{Interface}

The Watershed Modeling System (WMS) is a graphically based, spatial data processing environment that supports the complete GSSHA model deployment process. It greatly enhances the usability of the GSSHA model for the practicing hydrologic and hydraulic engineer. Project-specific spatial data products that characterize the spatial distribution of physical characteristics of the watershed or relevant system attributes can be readily imported into the WMS and subsequently transformed into GSSHA model specific features. These features can be displayed and easily parameterized or incorporated into simulated model processes. Geo- 
referenced imagery can also be imported into WMS and overlaid with supplementary project-specific spatial data sets, possibly representative of predetermined design/impact features. Coupling project information with the graphical display of relevant simulated states permits the high-level evaluation of project alternatives. The GSSHA model structure with its interface within WMS enables a more transparent simulation and evaluation of project alternatives than is possible with traditional hydrologic simulation models, viz., lumped and semidistributed model structures. The WMS was used extensively not only to develop but also evaluate the PSRP T1 and T2 GSSHA models representing existing and proposed project conditions. 


\section{Preferred Restoration Alternative}

Currently the project area is drained with a network of canals. A network of surface streets intended to allow access to residences disrupts overland flow. In the Tentatively Select Plan, the canals are plugged, and most of the roads are degraded (Figure 1). The flow conveyance currently provided by the canals is replaced with pumping stations and spreader berms, intended to restore sheet flow (Figure 1). Restoration features include the following:

1. The Prairie Canal is plugged in several locations along the length of the canal.

2. Merritt, Faka Union, and Miller canals remain open upstream of pump stations constructed as part of the plan and are plugged in several locations downstream of the pump stations.

3. A small section of the Faka Union Canal is left open near the Port of the Isles (POI).

4. Pump stations are constructed on Merritt, Faka Union, and Miller canals. These pump stations discharge water from the upstream canal to the spreader berms, which discharge water by gravity through a series of weirs in the berm creating sheet-flow downstream of the berms for wetland restoration purposes.

5. Most surface streets are degraded.

As shown in Figure 1, the project includes three areas requiring flood control: the Private Lands, the 6Ls, and the POI. Design flood protection features include the following:

1. The tie-back levee alignment starts east of the Merritt Canal and stops 1,829 m west of the Miller Pump Station.

2. A new interior drainage canal is to provide drainage for the Private Lands area north of the tieback levee by conveying storm water from a point where the existing drainage canal starts at 62nd Ave SE to the Miller pump station intake canal, where it will be pumped south into the PSRP.

3. A levee is built to protect the 6Ls area. 
Figure 1. Preferred alternative.

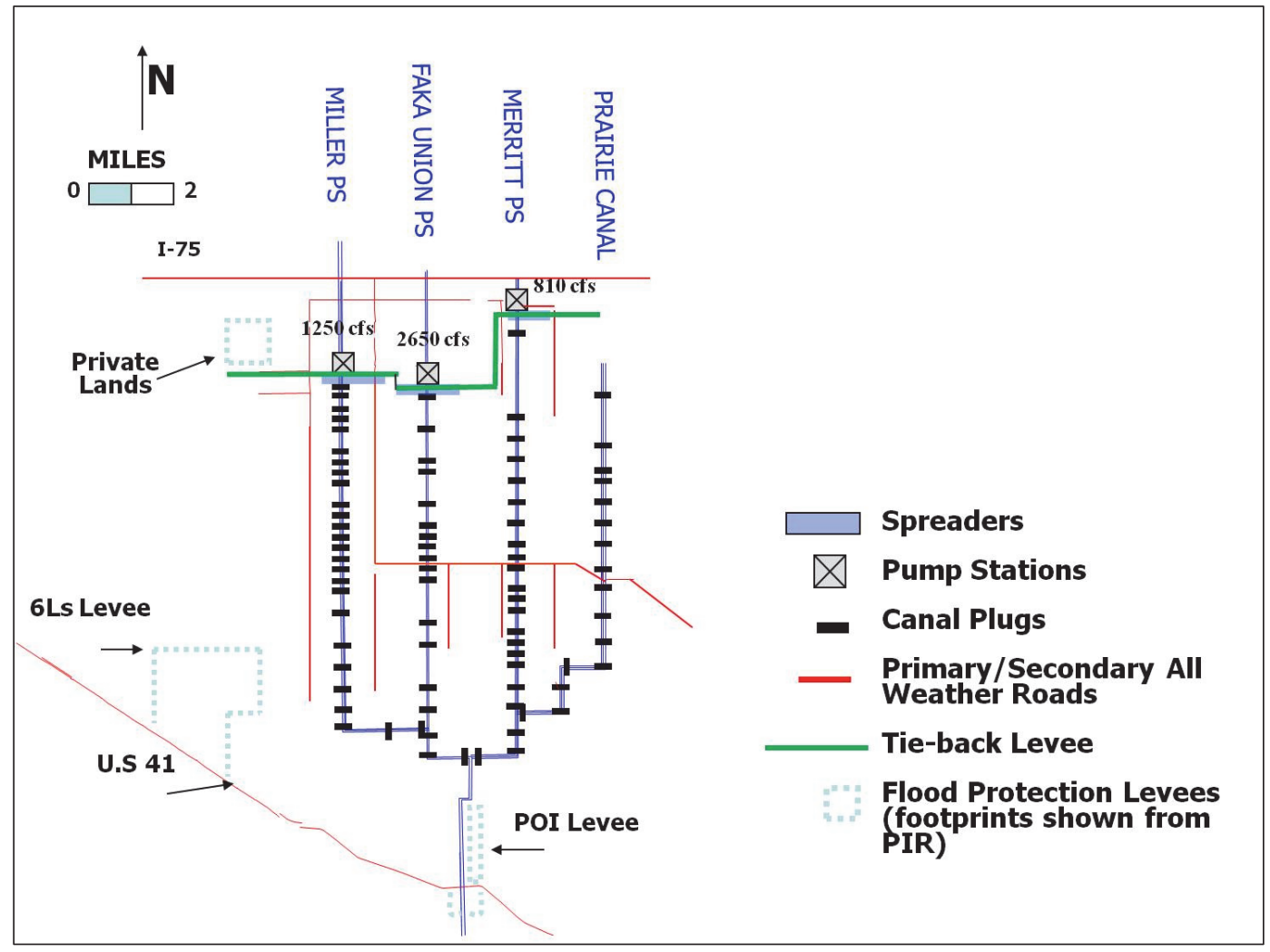




\section{Modeling Approach}

The modeling approach was to (1) develop the Existing Condition (Condition 1) T1 model, (2) calibrate and verify that model to observed stage and discharge data from two historical tropical storm events that hit the area, (3) include the features for the preferred alternative analysis (Conditions 2), (4) build the T2 models (Conditions 1 and 2) that derive boundary conditions from the larger T1 model, and (5) use this suite of models to simulate a series of return period storms events.

The T1 and T2 Existing Conditions (Condition 1) GSSHA model domains are shown in Figure 2. The figure also shows other features including relevant canals and structures, U.S. Interstate 75 (I-75), U.S. Highway (Hwy) 41, and the location of culverts along the U.S. Hwy 41 road way. At the T1 level, the Condition 1 (C1) model is the preproject condition without any of the PSRP features in place. All of the canals are intact; no pumps are installed; no flood protection features are in place.

The Proposed Project Model Condition model (Condition 2) is shown schematically in Figure 3. The Condition 2 (C2) model includes the preferred alternative features described in Section 2. As shown in the Figure, many of the canals in Figure 2 are plugged in Figure 3. These canals are not included in the model as 1D stream features in the C2 model. Water from the remaining canals is conveyed via a network of pumping stations and spreader berms (Figure 3). In Figure 3, the pumping stations are located on the canals behind the spreader berms.

To simplify the following discussion, the models will be referred to first as tier level (T1 or T2), followed by condition (C1) or (C2) (e.g., T1C2).

\section{Tier 1 (T1) model}

The T1 model provides the basis for the more refined T2 models. It includes sufficient detail to provide large scale impacts and boundary conditions for the T2 models. Important features of the T1 model are described below. 
Figure 2. T1 and T2 model domains and existing (C1) features.

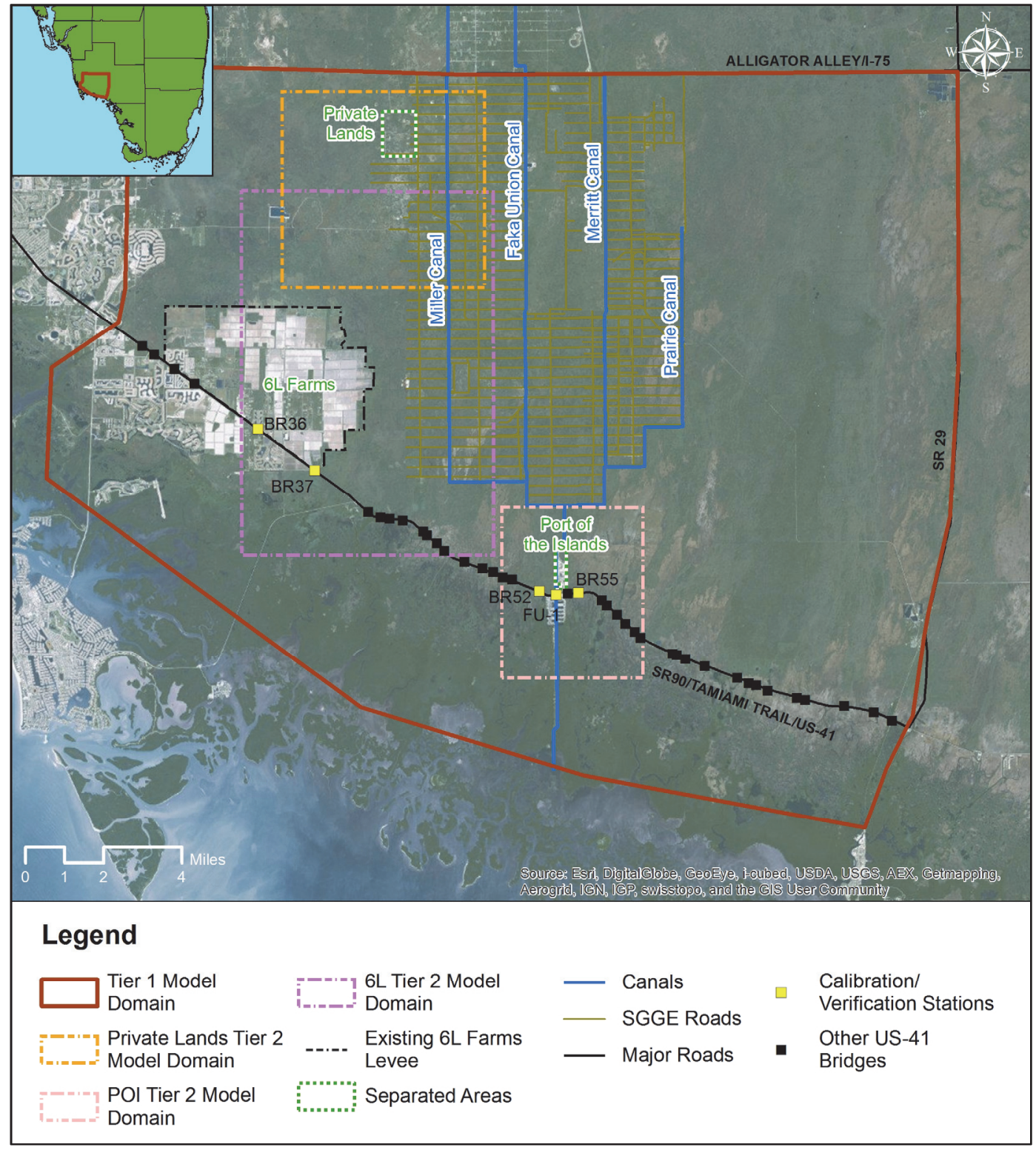


Figure 3. T 1 and T 2 model domains and proposed (C2) model features.

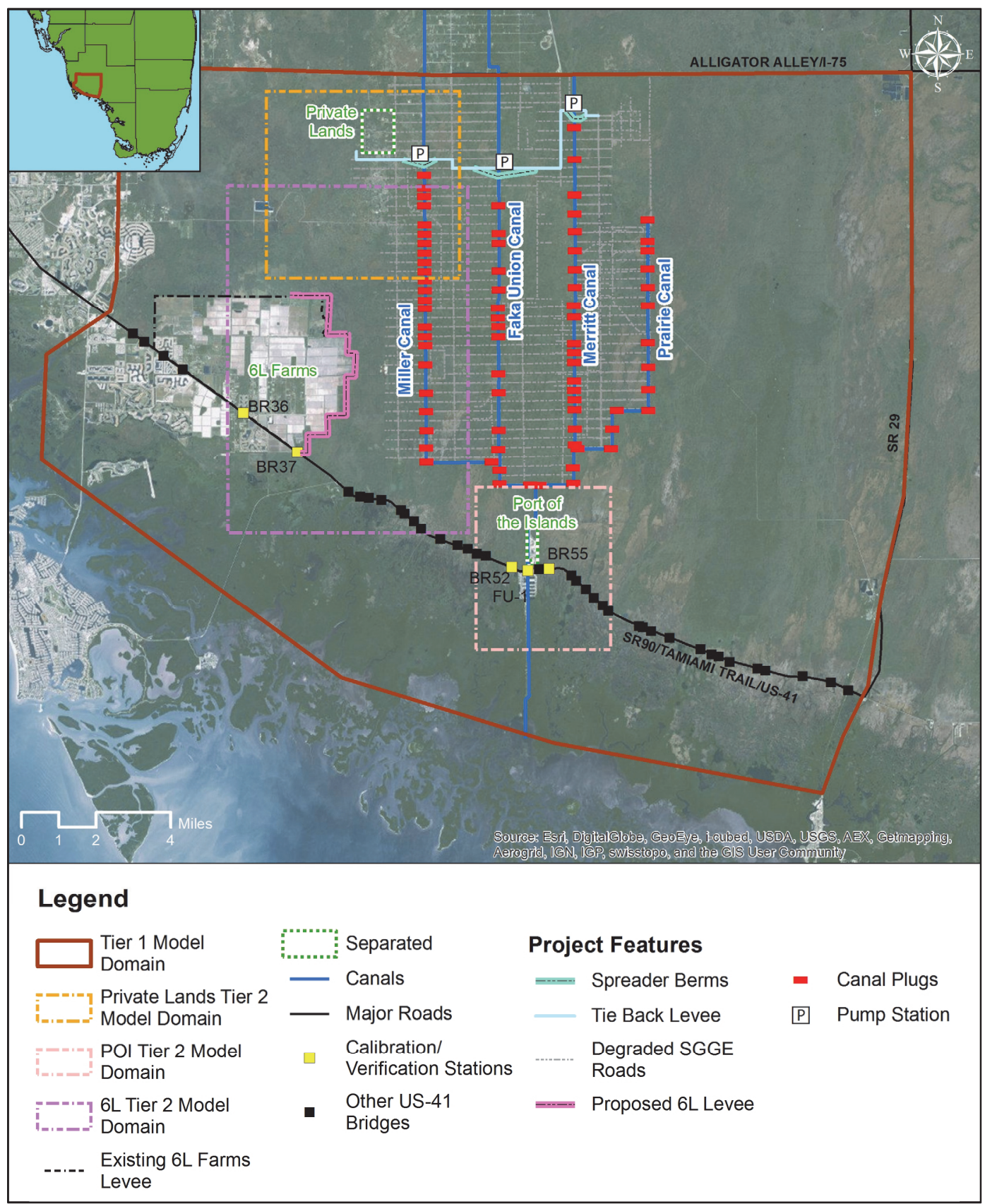

\section{Domain and boundary conditions}

The domain for the T1 model was selected based on available data, the need for coherent boundary conditions, and inclusion of important areas. The northern boundary of the model coincides with I-75 (Figure 2). The interstate has an embankment and a drainage canal with structures that control flow into the model domain. A no-overland flow condition was prescribed at the northern boundary. Flow into the domain from the area 
upstream of the model domain is only through the canals in the existing conditions and into the remnant canals immediately upstream the pump stations in C2. These boundary flows were extracted from a previous hydrodynamic model applied for the selection of the preferred alternative (USACE 2004). Flows into the canals were input as inflow hydrographs into the 1D stream network for $\mathrm{C} 1$ and as overland flow in $\mathrm{C} 2$ models.

The southern overland flow boundary of the model is a specified head boundary representative of the tidal stage fluctuations over the period of simulation, and it was derived from the model applied to select the preferred alternative (USACE 2004). The eastern and western boundaries are no-overland flow conditions, supported by local topography. Topography data were derived from a number of sources and composited into a series of topographic maps at various grid scales of 3, 5, 10,50, $100 \mathrm{~m}$, etc. WMS was used to determine the location of the topographic breaks. Model grid cell elevations were based on these same topographic data. Total area in the computational domain is $928 \mathrm{~km}^{2}$.

\section{Grid size and time-step}

A grid size analysis was performed to select the optimal grid size for the $\mathrm{T} 1$ model. In GSSHA, the optimal grid size captures all the relevant spatial data, without undue computational burden. A limitation of the grid size was the need to process and simulate the data on desktop computers. A number of grid sizes, from 30 to $200 \mathrm{~m}$, were tested. The final grid size of the T1 model was $120 \mathrm{~m}$. The simulation of the model with this grid size was facilitated by the inclusion of the overland flow structures that represent the bridges/culverts under U.S. Hwy 41, which are on the order of $30 \mathrm{~m}$ in length. The total number of grid elements in the domain is 64,920 . With the overland flow structures included in the model, this grid size was more than adequate to capture all salient spatial variability in the model domain. With this grid size, the model runs with time-steps on the order of $10 \mathrm{~s}$. The development of the overland flow structures in GSSHA is discussed in Section 4.

\section{Hydraulic structures and controls}

The PSRP C1 models contain numerous hydraulic structures and other overland flow control features, as described above. In GSSHA, the varying structures are simulated in the following ways: 
- Canals: All canals were simulated explicitly in the model as 1D channel flow. Cross-section and bottom elevation data were available from the as-built drawings and defined the canal cross sections and bottom elevations in the models. The same time varying stage applied at the southern overland flow boundary is used to specify the stage at the model outlet, the Faka Union Canal. This canal extends to the model boundary. Canals received specified flow hydrographs from the northern boundary and lateral flow from the overland. Flow exchanges between the canal and the overland cells occur in proportion to the water stage in the canal and surrounding overland cells. When the stage in the canal exceeds the ground surface elevation and the top of bank of the canal, water can flow out of bank onto the overland flow plane, depending on the water surface elevation on the overland flow plane. When the stage in surrounding overland cells is higher than the bank elevation of the channel and if the stage in the channel is lower than that of the surrounding cells, overland water flows into the canal. Weirs in the canals were included in the model. Relevant physical information was obtained from the previous hydrodynamic model (USACE 2004). Discharge coefficients were initially prescribed from this model and then calibrated to observed data. Canals that were either plugged or physically removed as part of the preferred alternative were removed from the stream network.

- Roads, Levees, Spreader Canals, and other Embankments: Overland flow impediments, described above, are included in the GSSHA model as embankments. Embankments block water across faces on the overland flow grid. Embankments block overland flow if the water level on the overland flow plane does not exceed the embankment height in the face of the cell blocking the water flow. When the embankment height is exceeded, flow over the embankment is computed by a broadcrested weir equation. Water surface elevations on both sides of the embankment are analyzed for backwater effects during these computations. Hydraulic structures through embankments are represented as overland flow structures with specified rating curves. The embankment for U.S. Hwy 41 contained 37 of these overland flow structures. Elevations for existing structures were obtained from asbuilt drawings. Elevations for proposed structures were obtained from design drawings. As a result of this modeling, some of the structure sizes, locations, and elevations were modified and reflected back into the modeling efforts. 
- Overland Roughness and Retention: Overland roughness is specified based on the 1995 land use and vegetation map. The model contains 18 land use/vegetation types. These land uses are employed to assign overland hydraulic roughness coefficients (Manning's coefficient) for the model. The primary land use/vegetation types in the model are hydric flatland (26\%), swamp forest (15\%), cypress (12\%), mangrove (12\%), wet prairie (9\%), and unknown (10\%). Roughness coefficients were originally assigned based on the previous hydrodynamic model applied during the alternative selection process and then calibrated to historic events, as described below. As described by the predominant vegetation, the PSRP domain is largely a swamp, and the area has depression features at both the grid and subgrid scale. These depression features retain water at low overland flow stages $\left(10^{-2} \mathrm{~m}\right.$ magnitude) but have little effect on flood flows, which may be several meters in depth. During model development, it was decided to minimize the explicit modeling of the fine-scale depression features by smoothing out the overland flow grid on a macroscale and then including depression storage, specified with an index map, for lost depression storage during the grid smoothing process. A detailed analysis was conducted to calculate the difference in storage between the smoothed $120 \mathrm{~m}$ model grid and the original $3 \mathrm{~m}$ topographic digital elevation model used to develop the GSSHA grid. The calculated depression storage was then applied to the GSSHA model as a map of retention depth. There were 42 separate depression storage areas identified and added to the GSSHA simulation. In GSSHA, flow on the overland flow plane will not occur until the retention depth has been exceeded; then flow above the retention depth is calculated with the Manning formula.

- Soils and Infiltration: While the event-based simulations of the suite of return period storms are simulated with a high water table assumption (i.e., no infiltration), the need to establish initial conditions for calibration and verification required that soils and infiltration be considered in the model. Soils were derived from the 1990 Natural Resources Conservation Service survey for Collier County, FL, as provided by the SFWMD. Four different soil classifications were used in the model: Immokalee, Boca, Riviera, and Sanibel.

\section{Tier 2 (T2) models}

T2 models were developed to refine and represent with higher fidelity some of the relevant hydraulic features in the proposed alternative. They were applied to refine the hydraulic design criteria for the proposed flood protection features and to analyze potential adverse effects of the areas 
where protection is needed. Three T2 inset models were developed for the existing $\left(\mathrm{C}_{1}\right)$ and proposed project conditions (C2): Private lands, 6Ls, and the POI. The model domains and relevant features are shown in Figures 4 through 8, with Figures 4, 6, and 8 showing the $\mathrm{C} 1$ features for the Private Lands, 6Ls, and POI models, respectively, and Figures 5, 7, and 8 showing the $\mathrm{C} 2$ features.

Figure 4. T1C1 Model domain for the Private Lands.

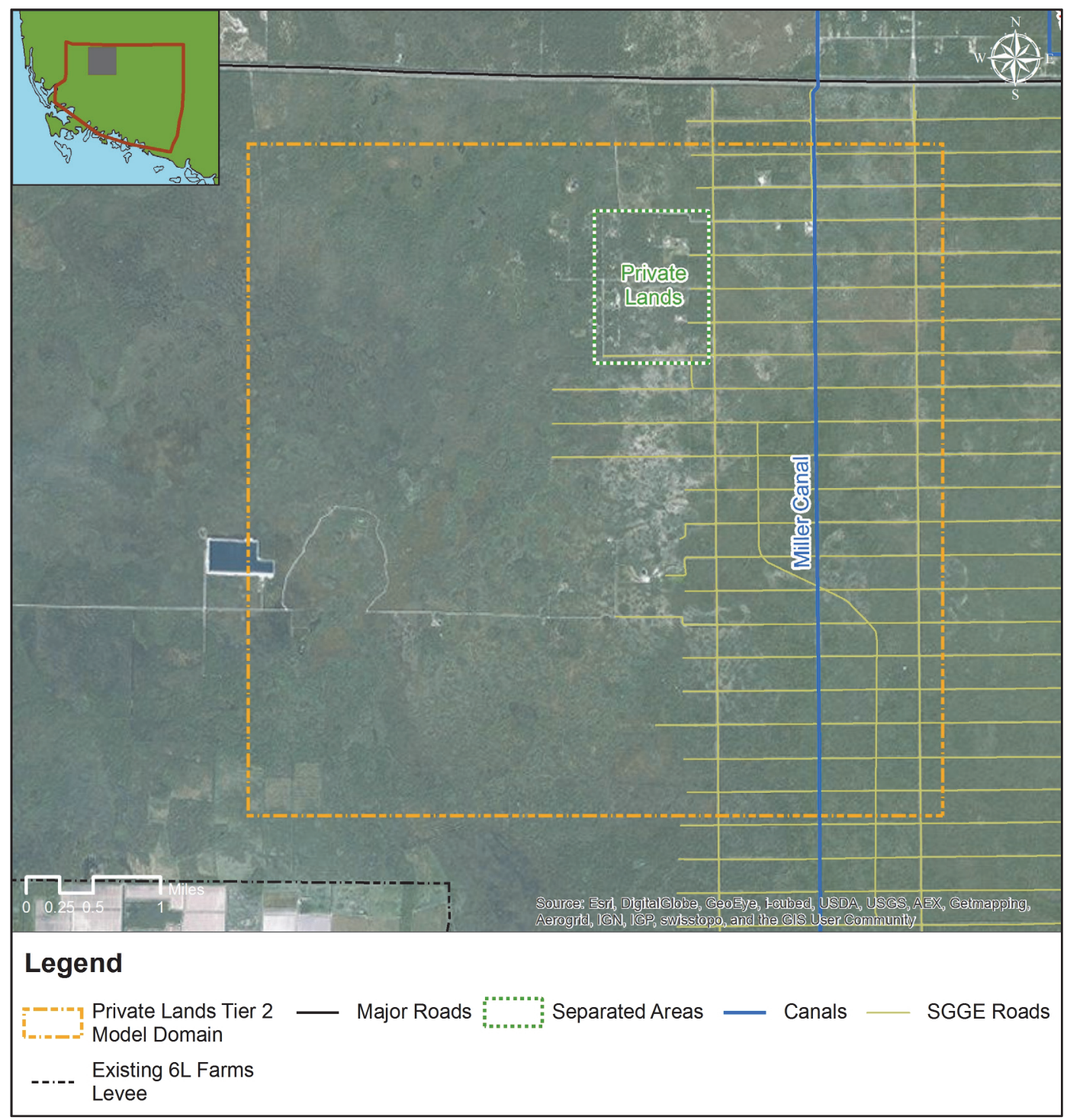


Figure 5. T2C2 model domain for the Private Lands.

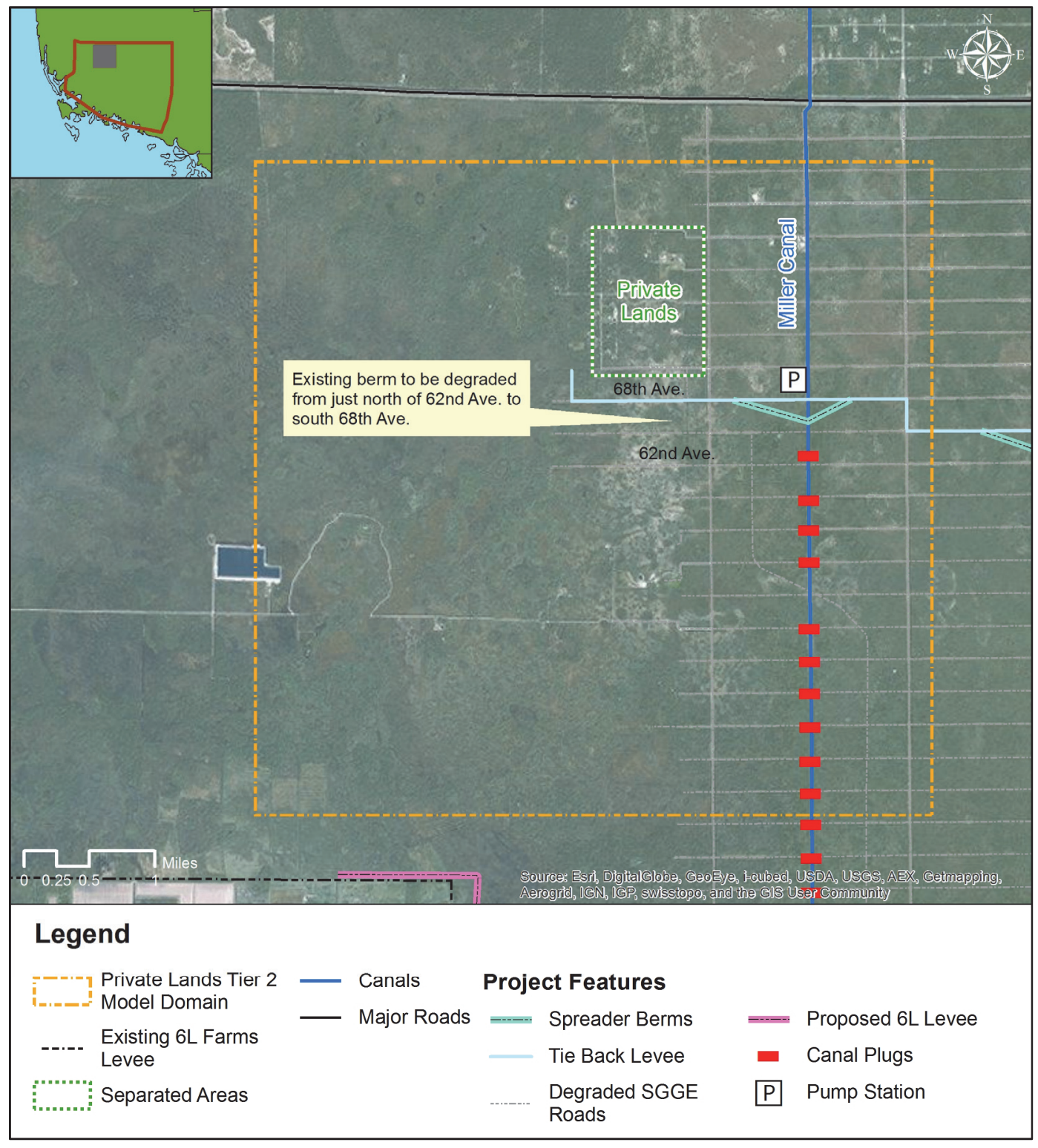


Figure 6. T2C1 domain and features for the 6Ls.

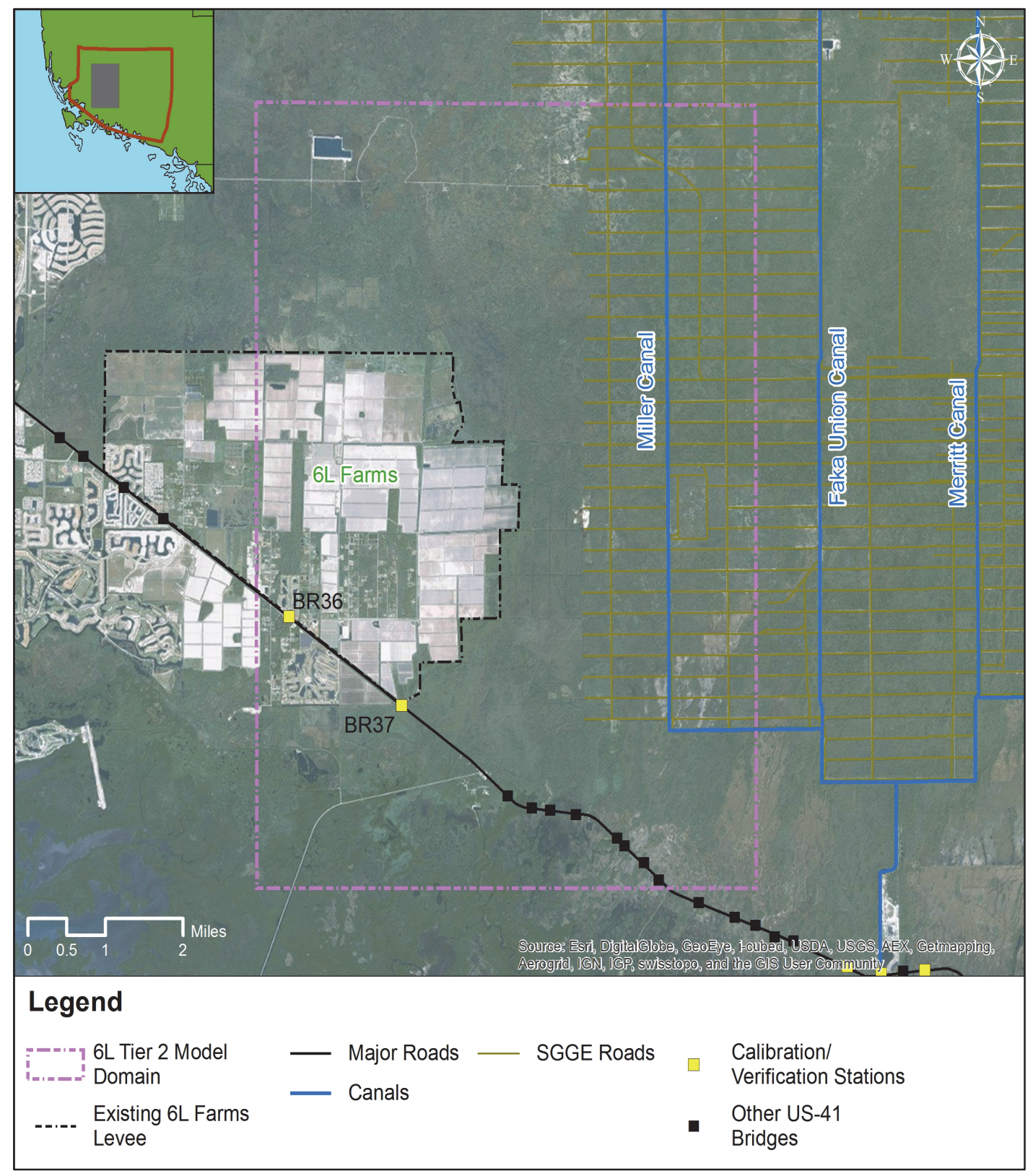


Figure 7. T2C2 domain and features for the $6 \mathrm{Ls}$.

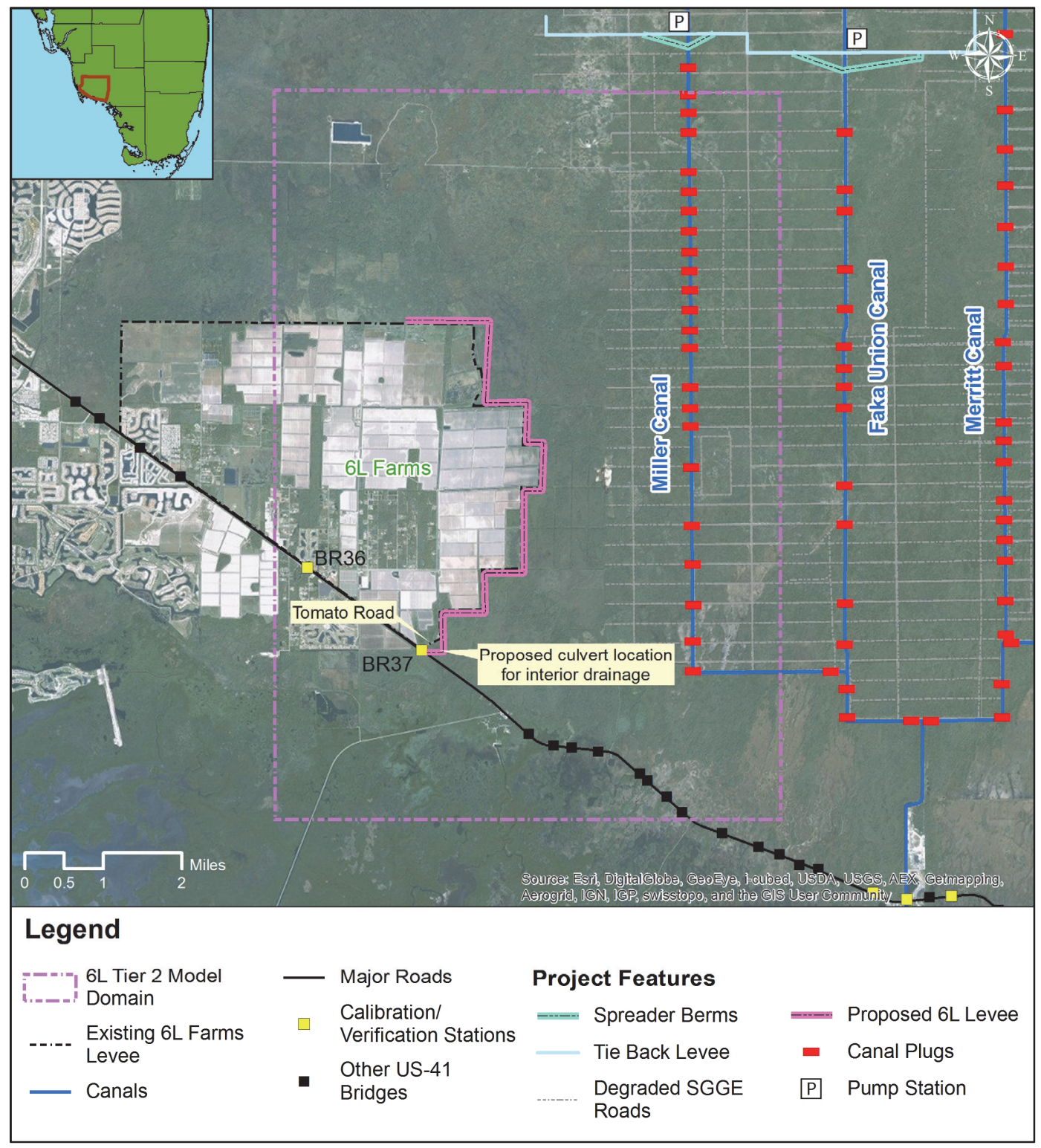


Figure 8. T2C1 and T2C2 domain and features for the POI.

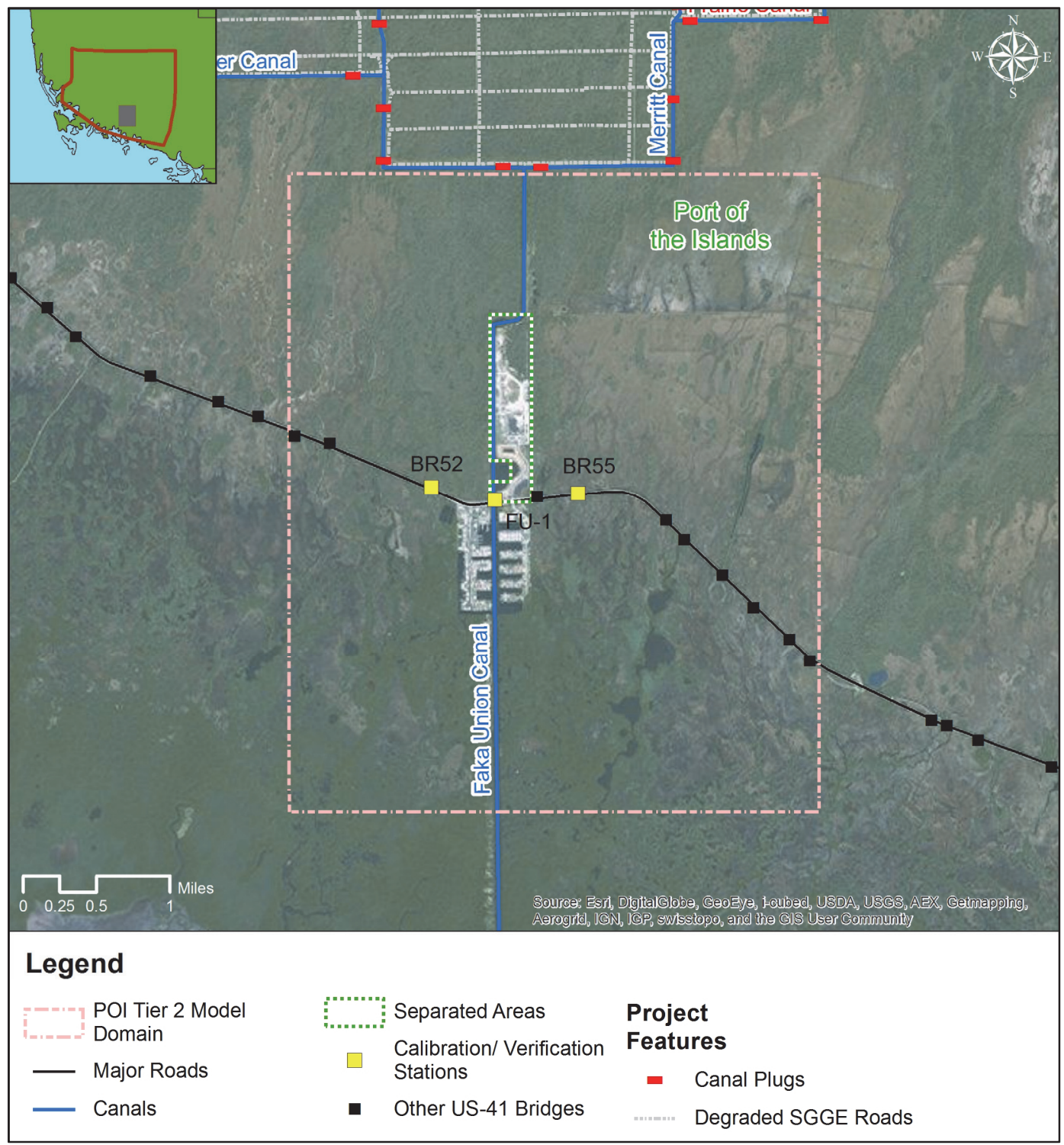

The T2 models share many common properties. The domains and grid sizes for the models were selected to allow the features in the respective models to be simulated accurately and efficiently. Specified head overland flow boundary conditions derived from the T1 models were specified along all the boundaries for all the models, unless otherwise noted below. All three models were constructed with a $20 \mathrm{~m}$ grid size and time-steps on the order of $10 \mathrm{~s}$. Specifics for each model are listed in Table 1. All simulation times refer to a single event simulation on an Intel Xeon X5760 CPU at $2.93 \mathrm{GHz}$. 
Table 1. Tier 2 models properties.

\begin{tabular}{|l|c|c|c|c|}
\hline T2 Model & $\begin{array}{c}\text { Model Area } \\
\left(\mathrm{km}^{2}\right)\end{array}$ & $\begin{array}{c}\text { T1 Area } \\
(\%)\end{array}$ & $\begin{array}{c}\text { No. of Grid } \\
\text { Cells }\end{array}$ & $\begin{array}{c}\text { Simulation Time } \\
(\mathrm{hr})\end{array}$ \\
\hline Private Lands & 67 & 7 & 167,648 & 4 \\
\hline 6Ls & 155 & 17 & 388,731 & 6.5 \\
\hline Port of the Isles & 41 & 4 & 102,492 & 2.5 \\
\hline
\end{tabular}

Many data sets in the T2 models were imported from the T1 model. Among these were soil properties, land use, roughness coefficients, retention depths, and any other parameter whose representation in these two domains was not dependent on model resolution. In the $\mathrm{C} 1$ models, the grid resolution allowed features such as roads to be explicitly included in the overland flow model. In $\mathrm{C} 2$ models, these features were assumed to be degraded. If a canal traversed the model domain, that canal was included in the T2 model. In all such cases, the upstream boundary condition was an input hydrograph, and the downstream boundary condition was a timevarying specified head. Items specific to each of the T2 models are described below.

\section{Private Lands model}

The T2 model domain for the Private Lands area is shown in Figures 4 and 5 for $\mathrm{C}_{1}$ and $\mathrm{C} 2$, respectively. The areas that cannot be adversely impacted by the proposed project are highlighted in the figures. Features specific to this model include the following:

1. The overland flow boundary condition on the southern boundary in $\mathrm{C} 2$ model was modified to a constant flow boundary condition to remove water from the domain instead of creating what was considered an artificial backwater effect due to overland stages imposed at this boundary.

2. In $\mathrm{C}_{2}$, the Miller Canal pump system was implicitly simulated by a time series of outflows assigned to model cells. This flow time series was representative of how the pump system would operate during the storm events simulated in this work (USACE 2004). The outflow time series for the Miller pump system are shown in Figure 9.

3. In $\mathrm{C} 2$, the proposed alternative includes the tieback embankment and the spreader berm as depicted in Figure 5. The spreader berm includes a series of 10 weirs designed to convey water from inside the internal spreader berm area into the landscape in a sheet flow regime. T2 model resolution allowed for the inclusion of these hydraulic details in the model. The design document drawings for the spreader berm, embankments, and weirs were used to define these features. 
Figure 9. Discharge time series for the Miller pump system.

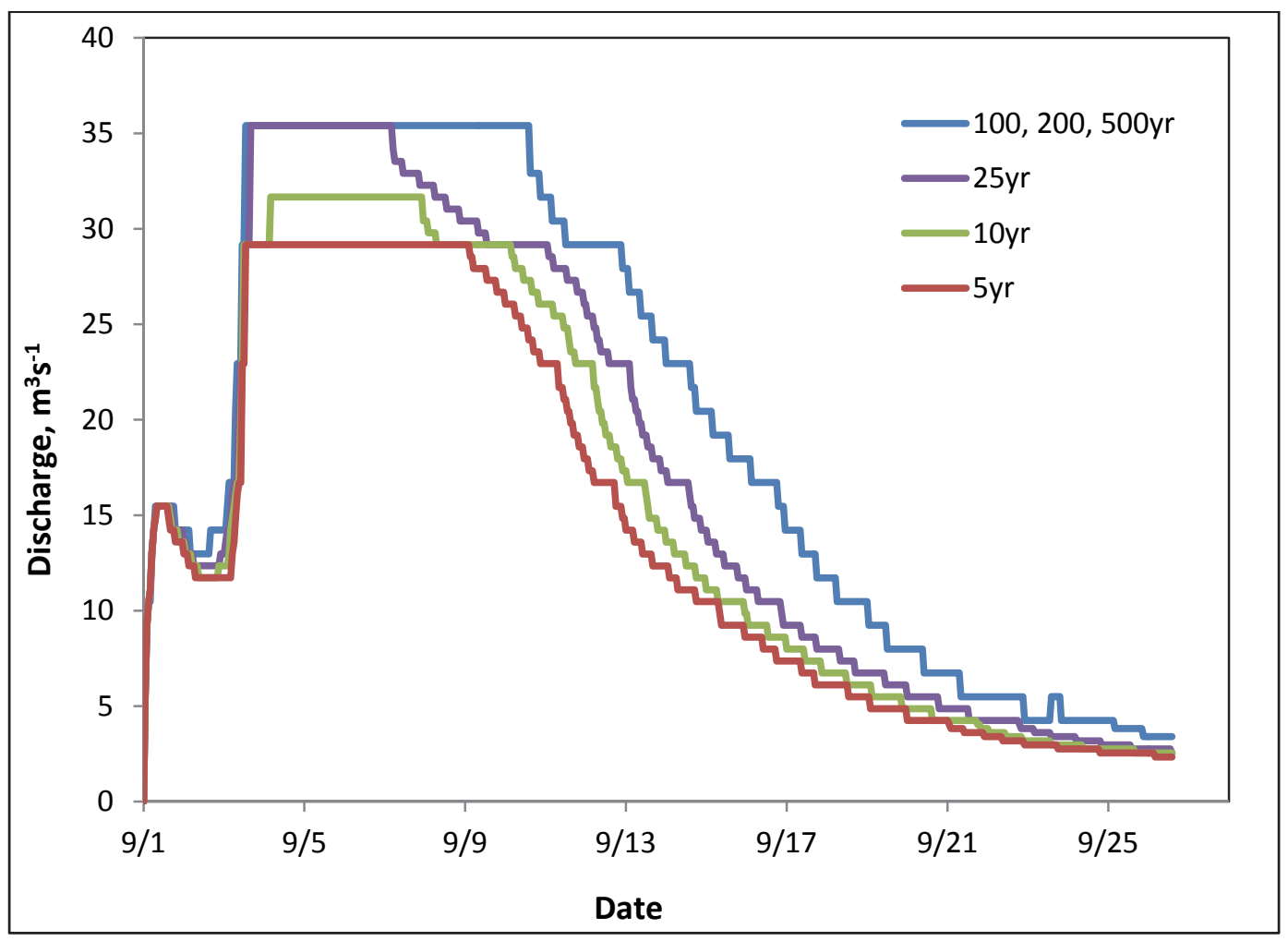

\section{Ls model}

The model domain for the T2 6Ls area is shown in Figures 6 and 7. Enclosed within the 6Ls levee are farm lands that shall not be adversely impacted by the PSRP restoration features and its operations. Features specific to this model include the following:

1. The only hydraulic structures applicable to $\mathrm{C} 1$ and $\mathrm{C} 2$ are the U.S. Hwy 41 culverts (Figures 6 and 7). There is one additional culvert included in the C2 model in the southern-most segment of the USACE proposed protective levee (Figure 7).

2. Embankments in $\mathrm{C} 1$ include the U.S. Hwy 41 road and the 6Ls levee.

3. In $\mathrm{C}_{2}$, the proposed alternative includes a protective levee (Figure 7) that is offset approximately $60 \mathrm{~m}$ from the $6 \mathrm{Ls}$ levee alignment. The goal of this feature is to provide flood protection to the areas enclosed by the $6 \mathrm{Ls}$ levee.

\section{Port of the Islands (POI) model}

The domain for the POI T2 1 and $\mathrm{T} 2 \mathrm{C} 2$ models is shown in Figure 8.

Features specific to this model include the following: 
1. For $\mathrm{C} 2$, there is a no flow boundary condition at the upstream end of the canal since in the preferred alternative, all canals segments south of the pump stations and north of this junction will be plugged. For the most downstream node of the canal, a stage boundary condition was assigned consistent with the T1 model.

2. The hydraulic structures in $\mathrm{C} 1$ and $\mathrm{C} 2$ are the U.S. Hwy 41 culverts (Figure 8) and an existing weir in the Faka Union Canal located just north of U.S. Hwy 41 (not shown). The proposed alternative does not consider additional hydraulic or control features in this area beyond the existing conditions.

3. The portion of the Faka Union Canal that will remain open in the preferred alternative is the only channel within the model domain. This applies to both conditions since the T2 model domain bisects the Faka Union Canal at the junction of the three main canals. The difference in how the canal is treated in $\mathrm{C}_{1}$ and $\mathrm{C} 2$ resides in the boundary conditions as described previously. No other canal is explicitly simulated in these conditions.

4. The preferred alternative does not alter the existing topography in the vicinity of $\mathrm{POI}$; therefore, topography in $\mathrm{C} 1$ and $\mathrm{C} 2$ was represented with only one source of data.

5. The only embankment in $\mathrm{C}_{1}$ and $\mathrm{C}_{2}$ is U.S. Hwy 41. In the PIR (USACE 2004), a protective embankment feature was being considered in the area around POI. T2C2 model simulations showed that this proposed feature did not significantly add flood protection beyond the existing conditions. 


\section{Gridded Surface Subsurface Hydrologic Analysis (GSSHA) Model Enhancements for Picayune Strand Restoration Project (PSRP)}

The PSRP presented many unique challenges to the modeling team. The project required models at varying levels of size and resolution, where the finer-resolution T2 models are subsets of the larger, coarser T1 model domain. To function properly, the higher-resolution T2 models had to extract temporally and spatially varying overland and channel boundary conditions from the larger T1 models. To facilitate the development of boundary conditions from the T1 model for application in the T2 models, the GSSHA model was modified such that when the T1 model was executed, the T1 model output the required spatially and temporally varying information needed for the T2 model simulations. The T2 model was then executed using the output from the T1 model as an input for boundary conditions. The T1 model writes output, overland depth and canal flow, for T1 model cells located in proximity to the T2 model boundary. The location of the T2 model boundary is a required input for the T1 model to produce the correct output. The T2 model reads the time varying overland depths and canal flows from the T1 model output file and uses them for the overland head and canal flow boundaries. Because the grid resolution of the two models is different, the overland depth values from the T1 model must be interpolated to the cells on the boundary of the T2 model grid. An inverse-distance-squared interpolation method is employed.

Another important development was the inclusion of point flow structures on the overland flow plane. A major highway, U.S. Hwy 41, traverses the lower portion of the model domain (Figures 1 and 2). Because the highway traverses a flood prone area, it is elevated approximately $3 \mathrm{~m}$. Several bridges/box culverts exist along the road embankment (Figures 1 and 2). Compared to the resolution of the T1 models, these features are relatively small and are not well represented as breaks in the embankment that represents U.S. Hwy 41 in the T1 models. Refining the T1 model to capture these features in the overland flow grid was not computationally reasonable. To allow the proper simulation of these important features, the ability to simulate point overland flow control structures was added to the GSSHA 
model. The overland point structures function by passing water from one overland flow cell to another based on a rating curve that relates either depth or difference in water surface elevation between the cells to flow. Overland cells that contain structures are specified on the overland flow boundary condition map and identified with a unique number that is associated with a rating curve. These overland point structures represented flow through the hydraulic structures along the U.S. Hwy 41 road embankment (Figure 1). The rating curves applied were developed from the MIKE SHE/11 hydrologic/hydraulic model used for the alternative assessment modeling (USACE 2004). 


\section{$5 \quad$ PSRP Model Calibration}

Thirteen parameters were specified as adjustable, and their names, meanings, and prescribed lower and upper bounds are listed in Table 2. The first parameter listed in Table 2, viz., $c h \_n$, holds the uniform Manning's roughness $n$ value for all channel links reflected in the $\mathrm{T} 1 \mathrm{C} 1$ model. The second parameter listed in Table 2, viz., $d c f$, holds the uniform value for the forward discharge coefficient for all five weirs that are reflected in the $\mathrm{T} 1 \mathrm{C} 1$ model. As the canals have been in place for 50 years without maintenance, the stream bed elevation values derived from the asbuilt drawings have considerable uncertainty and were adjusted with the third parameter listed in Table 2, viz., adj, which is the value to uniformly adjust all of the link node elevation values specified in the channel input file for the $\mathrm{T}_{1} \mathrm{C} 1$ model. Prior manual model calibration efforts with the $\mathrm{T} 1 \mathrm{C} 1$ model resulted in the specification of this adjustable model parameter. The fourth parameter listed in Table 2, viz., adj2, holds the value to uniformly adjust bankfull depth values, from their specified base values, for each channel link represented in the $\mathrm{T} 1 \mathrm{C} 1$ model. This parameter was specified to be adjustable based on expert solicitation ${ }^{1}$. The embankments along the canals are the result of spoil from the canals and are not uniform. The bankfull depth represents an effective bankfull depth. Base overland roughness values were uniformly modified via the value for the specified adjustable model parameter named mult1. Base retention depth values were uniformly modified via the value for the specified adjustable model parameter named mult2. Based on experience obtained via prior manual model calibration efforts with the $\mathrm{T} 1 \mathrm{C} 1$ model, the value for the specified adjustable model parameter named rain_mult permitted all input precipitation values to be increased, to a small reasonable degree, in attempts to improve model to measurement misfit during calibration. The values associated with the remaining final six specified adjustable model parameters, viz., rtc_mult_36,rtc_mult_37, rtc_mult_52, $r t c \_m u l t \_55, r t c \_m u l t \_w$, and rtc_mult_e pertain to uniform adjustment of their respective base rating curve values for the stage-discharge relationships for the culverts along U.S. Hwy 41, as indicated in Table 2.

${ }^{1}$ Charles W. Downer, 2012, personal communication, ERDC/CHL, Vicksburg, MS. 
Table 2. Specified adjustable parameters for the T1C1 model, their description, and specified lower and upper bounds.

\begin{tabular}{|l|l|l|l|}
\hline Parameter & Parameter description & $\begin{array}{l}\text { Lower } \\
\text { Bound }\end{array}$ & $\begin{array}{l}\text { Upper } \\
\text { Bound }\end{array}$ \\
\hline ch_n & Channel Manning's $n$ value & 0.025 & 0.075 \\
\hline dcf & $\begin{array}{l}\text { Forward discharge coefficient for weirs in channel } \\
\text { network }\end{array}$ & 1 & 5 \\
\hline adj & $\begin{array}{l}\text { Adjustment to all node elevation values in the } \\
\text { channel input file }\end{array}$ & -0.2 & 0.2 \\
\hline adj2 & $\begin{array}{l}\text { Adjustment to bankfull depth values in the channel } \\
\text { input file }\end{array}$ & -1 & 1 \\
\hline mult1 & Multiplier for original overland roughness values & 0.2 & 5 \\
\hline mult2 & Multiplier for original retention depth values & $1.00 \mathrm{E}-01$ & $1.00 \mathrm{E}+01$ \\
\hline rain_mult & Multiplier for original input rainfall values & 1 & 1.1 \\
\hline rtc_mult_36 & Multiplier for original rating curve values for 36 & $1.00 \mathrm{E}-02$ & $1.00 \mathrm{E}+02$ \\
\hline rtc_mult_37 & Multiplier for original rating curve values for 37 & $1.00 \mathrm{E}-02$ & $1.00 \mathrm{E}+02$ \\
\hline rtc_mult_52 & Multiplier for original rating curve values for 52 & $1.00 \mathrm{E}-02$ & $1.00 \mathrm{E}+02$ \\
\hline rtc_mult_55 & Multiplier for original rating curve values for 55 & $1.00 \mathrm{E}-02$ & $1.00 \mathrm{E}+02$ \\
\hline rtc_mult_w & $\begin{array}{l}\text { Multiplier for remaining original rating curve values } \\
\text { west of FU* }\end{array}$ & $1.00 \mathrm{E}-02$ & $1.00 \mathrm{E}+02$ \\
\hline rtc_mult_e & $\begin{array}{l}\text { Multiplier for remaining original rating curve values } \\
\text { east of FU }\end{array}$ & $1.00 \mathrm{E}-02$ & $1.00 \mathrm{E}+02$ \\
\hline
\end{tabular}

*Faka Union

Estimation of the 13 specified adjustable parameters for the $\mathrm{T} 1 \mathrm{C} 1$ model was undertaken by matching observed and simulated flows and stages at Faka Union 1 (FU-1), and also by matching observed and simulated stages at four ditch gaging locations along U.S. Hwy 41, viz., US41-Bridge36, US41-Bridge37, US41-Bridge52, and US41-Bridge55, for a single storm event (Tropical Storm Jerry: 20 Aug 1995, 14:00 - 26 Aug 1995, 11:00), resulting in 830 observations for the calibration process. Locations of the calibration/verification stations FU-1, US41-Bridge36, US41-Bridge37, US41-Bridge52, and US41-Bridge55 are shown in Figure 2. Six groups consisting of observations and their model-simulated counterparts composed the objective function as indicated in Table 3. The objective function, which is the quantitative measure of model to measurement misfit, is defined in the weighted-least-squares sense. Weight assignment for each observation group was adjusted such that at the beginning of the computer-based calibration, each observation group was seen to be of equal importance. 
Table 3. Unique observation groups defined to calibrate T1C1 model.

\begin{tabular}{|l|l|l|}
\hline Observation Group Name & Description & Number of Values \\
\hline $\mathrm{mf}$ & Modeled flows at FU-1 & 142 \\
\hline $\mathrm{ms}$ & Modeled stages at FU-1 & 142 \\
\hline ms36_1 & Modeled stages at US41-Bridge36 & 135 \\
\hline ms37_1 & Modeled stages at US41-Bridge37 & 134 \\
\hline ms52_1 & Modeled stages at US41-Bridge52 & 138 \\
\hline ms55_1 & Modeled stages at US41-Bridge55 & 139 \\
\hline
\end{tabular}

The Secant Levenberg-Marquardt (SLM) method, a nonlinear least squares minimization computer-based local search method (Skahill et al. 2009), as implemented by Skahill et al. (2012), was employed to efficiently calibrate the T1C1 model. With the exception of the two parameters named adj and adj2, which can take on negative values, the remaining 13 specified adjustable model parameters were log transformed in attempts to better accommodate scaling issues resulting from the use of different units for different parameters and to decrease the degree of nonlinearity of the parameter estimation problem; past experience has demonstrated that greater efficiency and stability of the parameter estimation process can often be achieved through this means (Skahill et al. 2009).

The SLM local search with the $\mathrm{T} 1 \mathrm{C} 1$ model was configured for efficiency. In particular, no full update of the model sensitivity matrix was employed together with single column cyclic updating ${ }^{1}$. The SLM local search completed after 33 forward model calls, reducing the objective function from an original value of 34,582 to a final value of 22,141. The final estimated model parameter set is listed in Table 4 together with an estimate of its uncertainty. Note that the confidence limits provide only an indication of parameter uncertainty. They rely on a linearity assumption which may not extend as far in parameter space as the confidence limits themselves. Clearly, the rating curve multipliers, viz., the specified adjustable model parameters named rtc_mult_36,rtc_mult_37, rtc_mult_52, rtc_mult_55, $r t c \_m u l t \_w$, and $r t c \_m u l t \_e$ were identified with the most uncertainty relative to the remaining model parameters. Computed model parameter sensitivities to all observations are listed in Table 5 (Doherty 2004). Modelsimulated results are most sensitive to the parameters named adj and adj2. The information shown in Figure 10 and listed in Table 6 summarizes

\footnotetext{
1 Refer to Skahill et al. (2009) and Skahill et al. (2012) for details regarding the SLM method and its implementation.
} 
model-to-measurement misfit at the final estimated parameter set. The computed Nash and Sutcliffe efficiency scores indicate a $\mathrm{T} 1 \mathrm{C} 1$ calibrated model of predictive value.

Table 4. Final estimated parameter set for the $\mathrm{T} 1 \mathrm{C} 1$ model with uncertainty estimate.

\begin{tabular}{|l|l|l|l|}
\hline \multirow{2}{*}{ Parameter } & \multirow{2}{*}{ Estimated Value } & \multicolumn{2}{|c|}{ 95\% Confidence Limits } \\
\cline { 3 - 4 } & 0.045844 & 0.044531 & \multicolumn{1}{|c|}{ Upper Limit } \\
\hline ch_n & 1.61301 & 1.521033 & 0.047195 \\
\hline dcf & 0.001531 & -0.004223 & 1.71055 \\
\hline adj & 0.000042 & 0.00002 & 0.007285 \\
\hline adj2 & 1.100165 & 0.988629 & 0.000063 \\
\hline mult1 & 0.856535 & 0.83239 & 1.224284 \\
\hline mult2 & 1.065394 & 1.043216 & 0.881381 \\
\hline rain_mult & 0.93399 & 0.682793 & 1.088043 \\
\hline rtc_mult_36 & 0.952339 & 0.608473 & 1.277602 \\
\hline rtc_mult_37 & 0.901433 & 0.698453 & 1.490534 \\
\hline rtc_mult_52 & 0.965863 & 0.763623 & 1.163402 \\
\hline rtc_mult_55 & 0.999786 & 0.684533 & 1.221665 \\
\hline rtc_mult_w & 0.96641 & 0.699074 & 1.460226 \\
\hline rtc_mult_e & & & 1.335978 \\
\hline
\end{tabular}

Table 5. Computed model parameter sensitivities to all observations.

\begin{tabular}{|l|l|}
\hline Parameter & Sensitivity \\
\hline ch_n & 1.409143 \\
\hline dcf & 2.01872 \\
\hline adj & 47.02873 \\
\hline adj2 & 624.9205 \\
\hline mult1 & 0.741138 \\
\hline mult2 & 1.830177 \\
\hline rain_mult & 3.064292 \\
\hline rtc_mult_36 & 0.62694 \\
\hline rtc_mult_37 & 0.87159 \\
\hline rtc_mult_52 & 1.406658 \\
\hline rtc_mult_55 & 1.438024 \\
\hline rtc_mult_w & 1.302043 \\
\hline rtc_mult_e & 0.537431 \\
\hline
\end{tabular}


Figure 10. Comparison of all simulated and observed data (FU-1 flow and stage, stage values at ditch locations numbered $36,37,52$, and 55 ) for the calibrated T1C1 model.

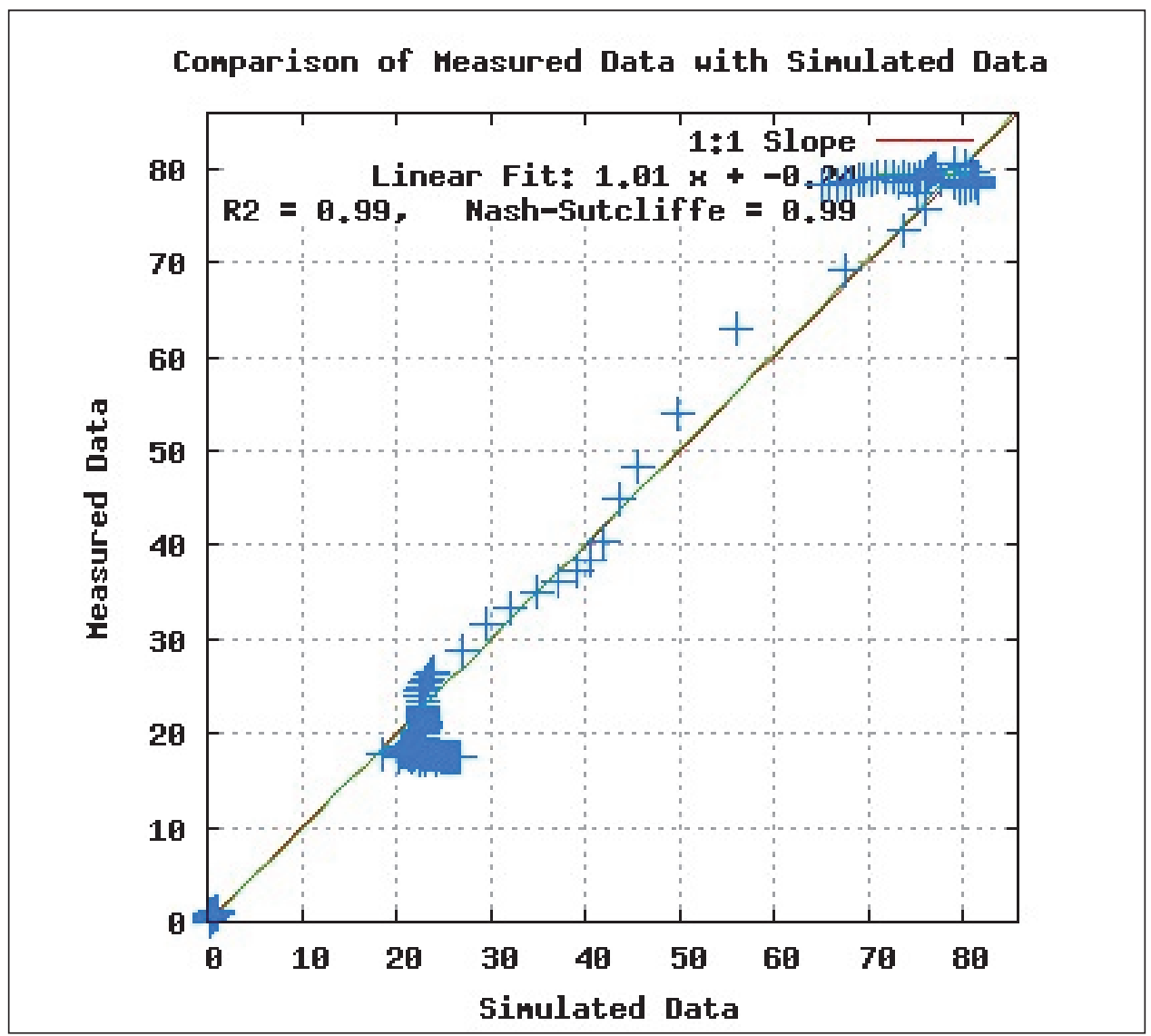

Table 6. Summary statistics of model to measurement misfit at the final estimated parameter set for the T1C1 model across different observation groups, including their subdivision or aggregation.

\begin{tabular}{|c|c|c|c|c|c|}
\hline Data Comparisons & $\mathrm{R}^{2}$ & $\begin{array}{l}\text { Nash-Sutcliffe } \\
\text { Efficiency } \\
\text { Scores }\end{array}$ & $\begin{array}{l}\text { Mean } \\
\text { Error } \\
(\mathrm{m})\end{array}$ & $\begin{array}{l}\text { Mean } \\
\text { Absolute } \\
\text { Error } \\
\text { (m) }\end{array}$ & $\begin{array}{l}\text { RMSE2 }^{2} \\
(\mathrm{~m})\end{array}$ \\
\hline FU-1 discharge data ${ }^{1}$ & 0.98 & 0.97 & $1.12^{1}$ & $3.93^{1}$ & $4.83^{1}$ \\
\hline FU-1 stage data & 0.97 & 0.97 & 0.00 & 0.03 & 0.04 \\
\hline All ditch stage data & 0.90 & 0.87 & -0.02 & 0.07 & 0.11 \\
\hline Ditch numbered 36 stages & 0.86 & 0.77 & -0.07 & 0.10 & 0.14 \\
\hline Ditch numbered 37 stages & 0.86 & 0.77 & -0.02 & 0.12 & 0.15 \\
\hline Ditch numbered 52 stages & 0.98 & 0.97 & 0.02 & 0.04 & 0.05 \\
\hline Ditch numbered 55 stages & 0.99 & 0.99 & 0.00 & 0.02 & 0.03 \\
\hline
\end{tabular}

1Discharge errors in $\mathrm{m}^{3} \mathrm{~s}^{-1}$.

${ }^{2}$ Root-mean-square error. 


\section{PSRP Model Predictions}

Hydrologic models are typically calibrated by adjusting parameters encapsulated in the simulator until there is an acceptable level of agreement between a set of historical data and their model simulated counterparts. The parameters obtained via calibration are often used in the model to predict system behavior for one or more predefined scenarios of interest. Regardless of the calibration method employed and the type of model applied (e.g., empirical or physics based), some if not all of the parameter values obtained through the calibration process possess a degree of quantifiable uncertainty. This is because the observed data contain measurement errors and also because the model never perfectly represents the watershed system or exactly fits the observation data. Where model parameters are uncertain, so too will be model predictions.

For the PSRP alternatives modeled at the T1 level, nonlinear calibration constrained predictive analysis was performed (Cooley and Vecchia 1987; Vecchia and Cooley 1987). Due to computational constraints, project alternatives evaluated at the T2 level only permitted a less-intensive linear uncertainty analysis (Doherty 2004). However, due to time limitations, linear uncertainty analyses were also performed with the $\mathrm{T} 1 \mathrm{C} 2$ model for six locations along the proposed tieback levee system. These uncertainty analyses that were performed for the PSRP project alternatives supported risk-based hydrologic design in that the upper $95 \%$ prediction limit was computed for stages at specific locations of interest in each case. Levee superiority analysis was performed to assess whether the levee crest was at least $0.6 \mathrm{~m}$ greater than the $95 \%$ confidence level for the 100-year event.

Nonlinear calibration constrained predictive uncertainty analysis (Cooley and Vecchia 1987; Vecchia and Cooley 1987) involves maximizing/ minimizing a specific prediction of interest, $s$, while keeping the calibration model effectively in a calibrated state. In particular, the objective function value associated with the estimated parameter set, $\Phi(\underline{\mathbf{p}})$, is relaxed to accommodate for the desired level of confidence, $1-\alpha$, as indicated in the following:

$$
\Phi(\mathbf{p})-\Phi(\underline{\mathbf{p}}) \leq m \sigma_{r}^{2} F_{\alpha}(m, n-m)
$$


$\Phi(\mathbf{p}), m, \sigma_{r}^{2}, F_{\alpha}(m, n-m)$, and $n$ represent the objective function for a parameter set $\mathbf{p}$, the number of specified adjustable model parameters, the reference variance, the $F$ distribution, and the number of non-zero weighted observations employed to calibrate the model. The simultaneous prediction confidence interval is given by

$$
\text { Prob }\left|\underline{s}-\sqrt{m F_{\alpha}(m, n-m)} \sigma_{s} \leq s \leq \underline{s}+\sqrt{m F_{\alpha}(m, n-m)} \sigma_{s}\right|=1-\alpha
$$

where $\sigma_{s}$ is the standard deviation of $s .{ }^{1}$ Application of this methodology generally involves the development of a composite model that is comprised of the model run under calibration conditions followed by the predictive model representative of a given alternative scenario run under predictive conditions. Simulation of the predictive model yields the specific unique prediction that is to be maximized/minimized, as mentioned above.

While tractable for many model deployments, nonlinear predictive analysis is nonetheless nontrivial in terms of its model simulation time requirements. If forward model execution times are prohibitively expensive, then one can employ a linear analysis wherein the only additional postcalibration computational burden is to compute the sensitivity of the prediction of interest to the set of specified adjustable model parameters. This will require at a minimum $(m+1)$ forward model calls. The variance of the uncertainty of the prediction in this case is given by

$$
\sigma_{s}^{2}=y^{t}\left(X^{t} C^{-1}(\epsilon) X+C^{-1}(p)\right)^{-1} y
$$

where $y, X, C(\epsilon)$, and $C(p)$ represent the sensitivity of the prediction to the specified adjustable model parameters, the model sensitivity matrix at the estimated parameter set, the covariance of the error term for measurement noise, and the covariance matrix associated with the estimated parameter set. All of the input in the equation immediately above, with the exception of the prediction sensitivity vector $y$, is information that was obtained at the end of the computer-based model calibration for the $\mathrm{T} 1 \mathrm{C} 1$ model.

Nonlinear calibration constrained predictive uncertainty analysis simulations were performed to compute the maximum simulated stage, at

1 For complete details, see Cooley and Vecchia (1987) and Vecchia and Cooley (1987). 
the 95\% confidence level, at two grid cell locations for the $\mathrm{T}_{1} \mathrm{C} 2 \mathrm{POI}$ model. The noted, two GSSHA model grid cell locations are indicated in Figure 11. The predictive model was forced with precipitation data representative of the 5-day, 100-year design condition. Table 7 summarizes the two nonlinear predictive analysis runs.

Figure 11. The T1C1 uncertainty analysis assessment points.

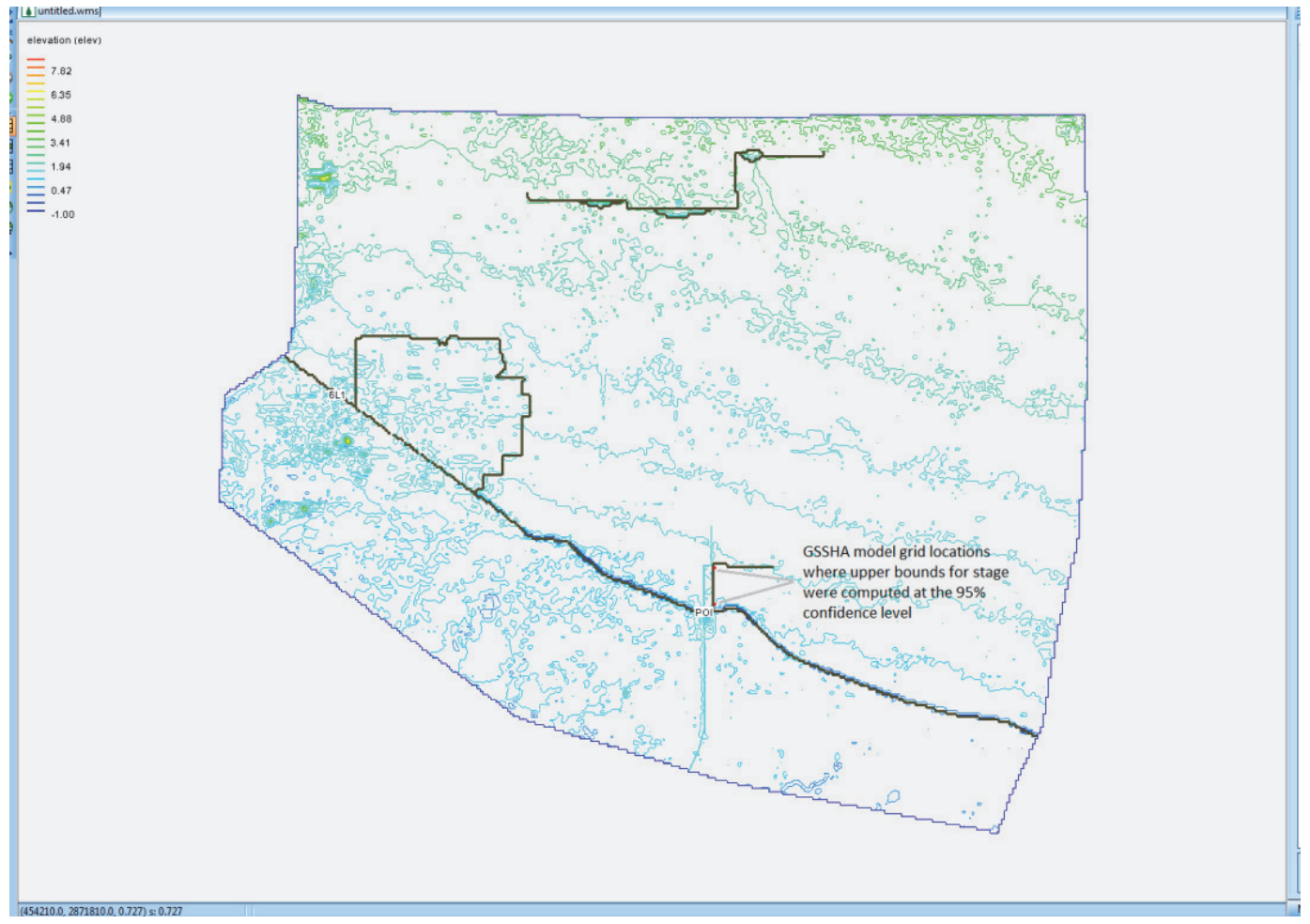

Table 7. Maximum predicted stage values, at the $95 \%$ confidence level, simulated by the T1C2 GSSHA model forced with the 5-day, 100-year design storm.

\begin{tabular}{|l|l|}
\hline $\begin{array}{l}\text { Predictive GSSHA Model } \\
\text { Grid Cell Location }(\mathrm{i}, \mathrm{j})\end{array}$ & $\begin{array}{l}\text { Maximum Predicted Stage } \\
(\mathrm{m})\end{array}$ \\
\hline 171,179 & 1.62 \\
\hline 184,179 & 1.64 \\
\hline
\end{tabular}

Five linear predictive uncertainty analyses were performed to compute the maximum predicted stage, at the $95 \%$ confidence level, at five distinct locations associated with the T2 level GSSHA Private Lands model. These locations are designated in Figure 12. As with the POI predictive model, the composite predictive Private Lands model was forced with precipitation data representative of the 5-day, 100-year design storm. For each of the five locations, the vector $y$ in Equation (3) above had to be determined 
from the composite predictive Private Lands model. The computation of the prediction sensitivity vector $y$ in each case required six forward model calls of the composite predictive Private Lands model. Only six forward model calls were required to populate the vector $y$ because the specified adjustable model parameters named $d c f$, adj2, rtc_mult_36, rtc_mult_37, $r t c \_m u l t \_52, r t c \_m u l t \_55, r t c \_m u l t \_w$, and $r t c \_m u l t \_e$ were all held fixed at their estimated values as listed in Table 4 because by virtue of the project alternative they were known to not be relevant. At each location, after the vector $y$ was determined via first-order finite difference calculations, Equation (3) was subsequently used to compute the uncertainty of the prediction of maximum stage at the $95 \%$ confidence level. Table 8 summarizes the linear uncertainty analyses for the five locations for the composite predictive Private Lands model.

Figure 12. T2C2 Private Lands model. The black dots indicate the approximate locations where linear predictive uncertainty analyses were performed to compute the maximum simulated stage at the $95 \%$ confidence level when the model is forced with the design storm.

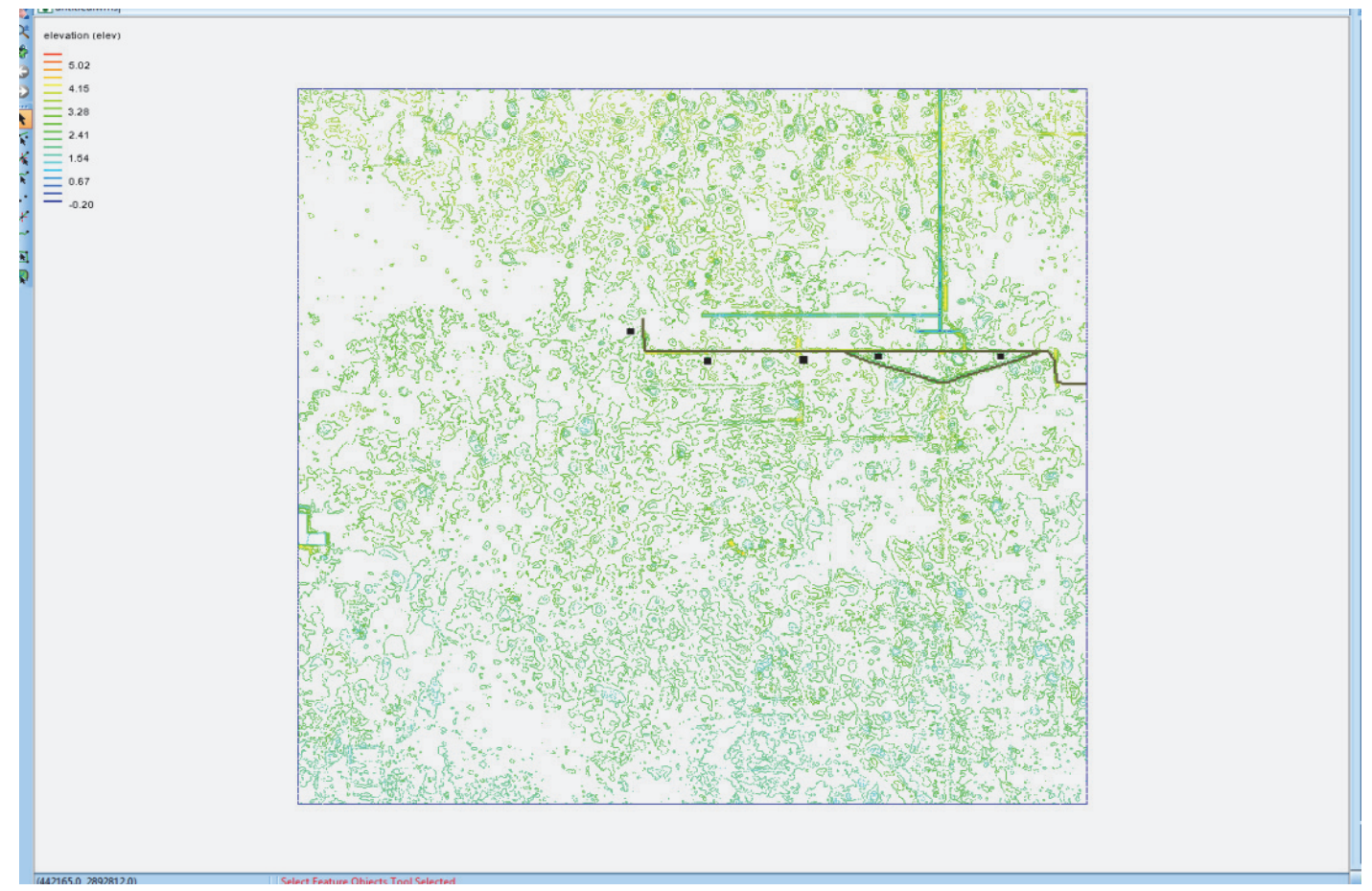


Table 8. Maximum predicted stage values, at the $95 \%$ confidence level, simulated by the T2C2 Private Lands GSSHA model forced with the 5-day, 100-year design storm.

\begin{tabular}{|l|l|}
\hline $\begin{array}{l}\text { Predictive T2 GSSHA Private Lands } \\
\text { Model Grid Cell Location }(\mathrm{i}, \mathrm{j})\end{array}$ & $\begin{array}{l}\text { Maximum Predicted Stage } \\
(\mathrm{m})\end{array}$ \\
\hline 153,311 & 3.40 \\
\hline 153,370 & 3.46 \\
\hline 136,179 & 3.18 \\
\hline 152,200 & 3.14 \\
\hline 152,269 & 3.29 \\
\hline
\end{tabular}

Six linear predictive uncertainty analyses were performed to compute the maximum predicted stage, at the $95 \%$ confidence level, at six distinct locations associated with the T2 level GSSHA 6Ls model. These locations are designated in Figure 13. As with the previous predictive models, the 6Ls model was forced with precipitation data representative of the 5-day, 100-year design storm. For each of the six locations, the vector $y$ in Equation (3) above had to be determined from the composite predictive $6 \mathrm{Ls}$ model. The computation of the prediction sensitivity vector $y$ in each case required 14 forward model calls of the composite predictive 6Ls model. At each location, after the vector $y$ was determined via first-order finite difference calculations, Equation (3) was subsequently used to compute the uncertainty of the prediction of maximum stage at the $95 \%$ confidence level. Table 9 summarizes the linear uncertainty analyses for the six locations for the composite predictive $6 \mathrm{Ls}$ model.

A representation of the T1C2 GSSHA model is depicted in Figure 14. Six linear predictive uncertainty analyses along with a single nonlinear analysis were performed to compute the maximum predicted stage, at the $95 \%$ confidence level, at six distinct locations associated with the $\mathrm{T} 1 \mathrm{C} 2$ model. These locations are shown in Figure 14, and the maximum water elevation in the corresponding grid cells is listed in Table 10. The predictive $\mathrm{T}_{1} \mathrm{C} 2$ model was forced with precipitation data representative of the 5-day, 100year design storm. For each of the six locations, for the linear analysis, the vector $y$ in Equation 3 above had to be determined from the predictive model. The computation of the prediction sensitivity vector $y$ in each case required 14 forward model calls of the predictive model. At each location, after the vector $y$ was determined via first-order finite difference calculations, Equation (3) was subsequently used to compute the uncertainty of the prediction of maximum stage at the $95 \%$ confidence level. Table 10 summarizes the linear and nonlinear uncertainty analyses for the six locations for the T1C2 GSSHA model. 
Figure 13. T2C2 6Ls model. The black dots indicate the approximate locations where linear predictive uncertainty analyses were performed to compute the maximum simulated stage at the $95 \%$ confidence level when the model is forced with the design storm. Two separate analyses were performed at distinct grid cell locations in the vicinity of the southernmost black dot indicated in the figure.

$$
\begin{aligned}
& \text { elevation (elev) } \\
& \bar{\equiv}^{6.85}
\end{aligned}
$$

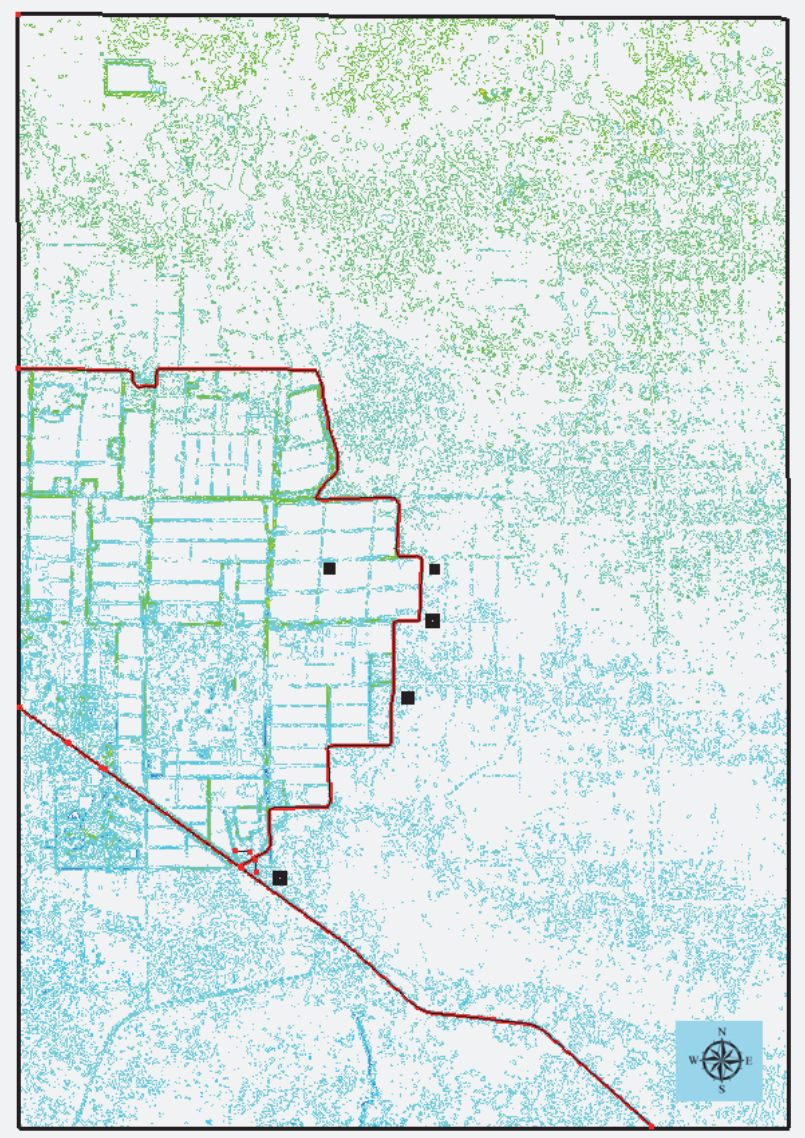

Table 9. Maximum predicted stage values, at the $95 \%$ confidence level, simulated by the T2 predictive $6 \mathrm{Ls}$ model forced with the 5-day 100-year design storm.

\begin{tabular}{|l|l|}
\hline $\begin{array}{l}\text { Predictive T2 GSSHA Miller } \\
\text { Model Grid Cell Location }(\mathrm{i}, \mathrm{j})\end{array}$ & $\begin{array}{l}\text { Maximum Predicted Stage } \\
(\mathrm{m})\end{array}$ \\
\hline 379,279 & 2.438 \\
\hline 354,215 & 2.028 \\
\hline 461,260 & 2.183 \\
\hline 582,174 & 4.002 \\
\hline 411,279 & 2.300 \\
\hline 579,175 & 2.470 \\
\hline
\end{tabular}


Figure 14. T1C2 model. The six pink dots indicate the approximate locations where linear and nonlinear predictive uncertainty analyses were performed to compute the maximum simulated stage at the $95 \%$ confidence level when the T1C2 model is forced with the design storm.

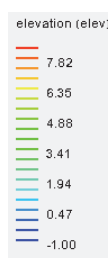

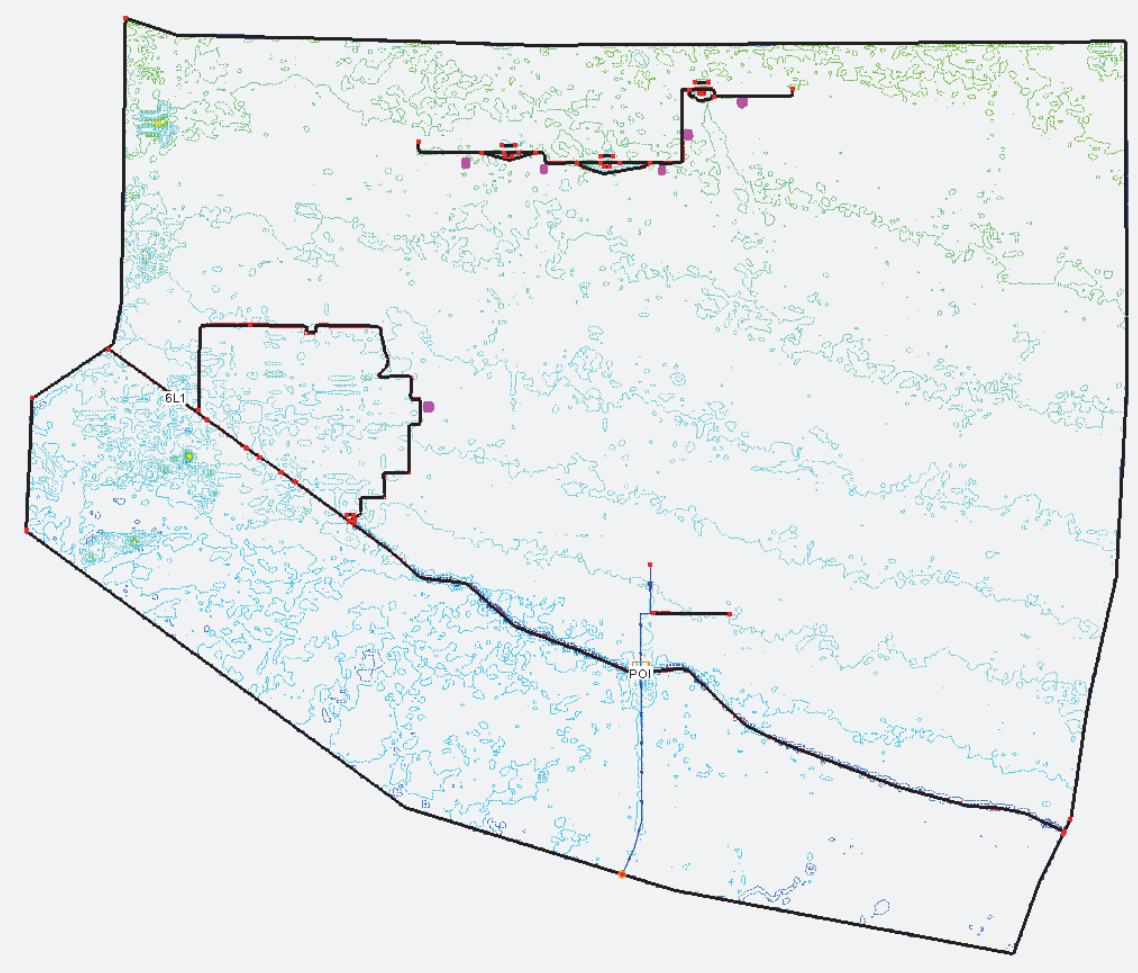

Table 10. Maximum predicted stage values, at the $95 \%$ confidence level, simulated by the T1 level GSSHA predictive C2 model forced with the 5-day 100-year design storm.

\begin{tabular}{|l|l|}
\hline $\begin{array}{l}\text { Predictive T2 GSSHA Miller } \\
\text { Model Grid Cell Location }(\mathrm{i}, \mathrm{j})\end{array}$ & $\begin{array}{l}\text { Maximum Predicted Stage } \\
(\mathrm{m})\end{array}$ \\
\hline 24,205 & $\begin{array}{l}3.685 \text { (linear), 3.692 } \\
\text { (nonlinear) }\end{array}$ \\
\hline 33,188 & 3.635 \\
\hline 41,126 & 3.199 \\
\hline 43,148 & 3.279 \\
\hline 43,181 & 3.320 \\
\hline 111,114 & 2.392 \\
\hline
\end{tabular}




\section{Maximum Flood Levels and Implications to the Protection Features Design}

To quantify the residual flooding caused by the proposed PSRP restoration features, the T2 values of gridded maximum flood stage in $\mathrm{C} 1$ were subtracted from the $\mathrm{T}_{2} \mathrm{C}_{2}$ flood stages for all storm event frequencies analyzed in this study. The results of this comparison along with the PSRP model predictive analysis discussed in the previous section allowed for further refinement of the proposed restoration features.

The cell-by-cell difference of the maximum flood extent between T2C2 and $\mathrm{T} 2 \mathrm{C} 1$ for the 100-year storm event is shown at POI in Figure 15. As shown in the figure, this analysis indicated either no change in water level or a lower water level for the $\mathrm{C} 2$ model relative to the $\mathrm{C} 1$ model. These results indicate that the proposed protection feature that was conceptualized as a protective levee just east of the developed areas north of U.S. Hwy 41 does not provide any additional flood protection relative to the existing conditions. Moreover, the proposed restoration features for the PSRP will most likely alleviate flooding conditions in this vicinity. Results for all other storm events showed similar trends to the 100-year frequency storm. A water surface profile for the 10-year and 100-year storm events just east of the developed areas showed that water levels for $\mathrm{C} 2$ are consistently lower than C1 (Figure 16).

Doing a similar analysis for the Private Lands $\mathrm{T} 2 \mathrm{C} 2$ model showed that the tie-back levee protective feature that was originally conceptualized in the PIR (Figure 17) extending approximately 3,000 $\mathrm{m}$ west of the Miller pump station to the south of the Private Lands area could be reduced to approximately $1,800 \mathrm{~m}$ in length without decreasing the level of flood protection this feature was designed to provide. This is illustrated in Figure 17, where the difference in maximum flood extent between $\mathrm{C} 2$ and $\mathrm{C} 1$ is shown on a cell-by-cell basis. These results show that increases in water depths in $\mathrm{C} 2$ relative to $\mathrm{C} 1$ do not extend to the private lands areas. Water surface profiles along the recommended levee extension, Figure 17, are shown in Figure 18. 
Figure 15. Cell-by-cell difference of maximum flood extent for the POI T2 model.

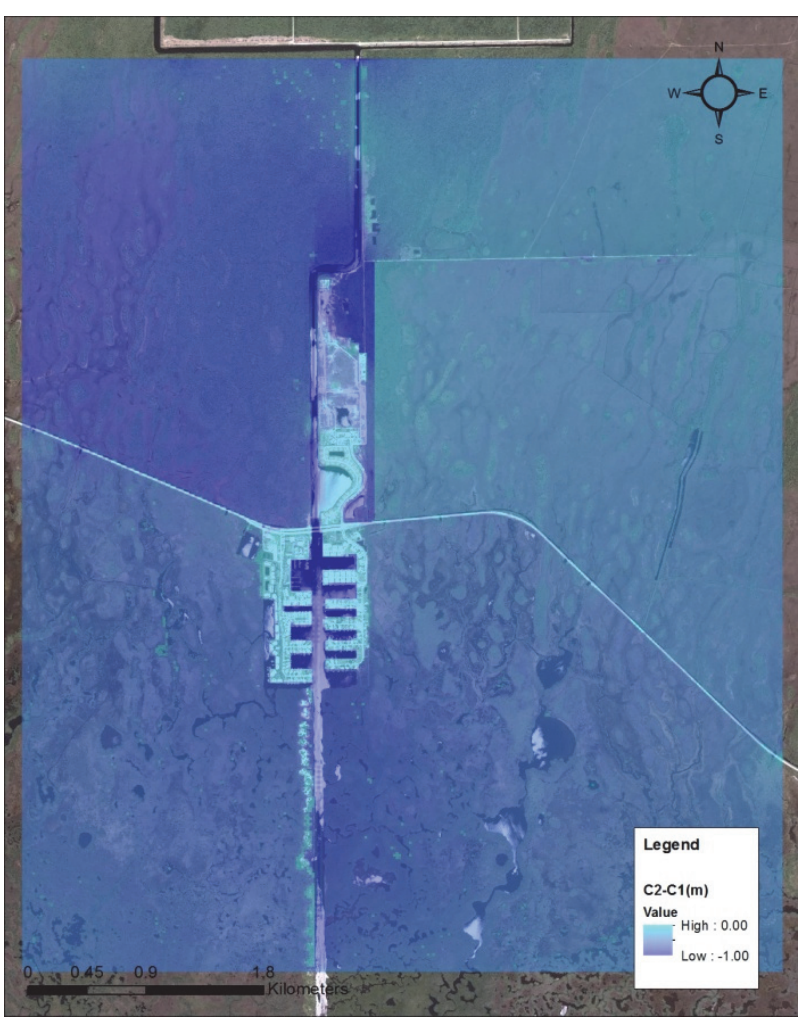

Figure 16. Water surface profiles along the east boundary of the developed areas in the POI T2 model.

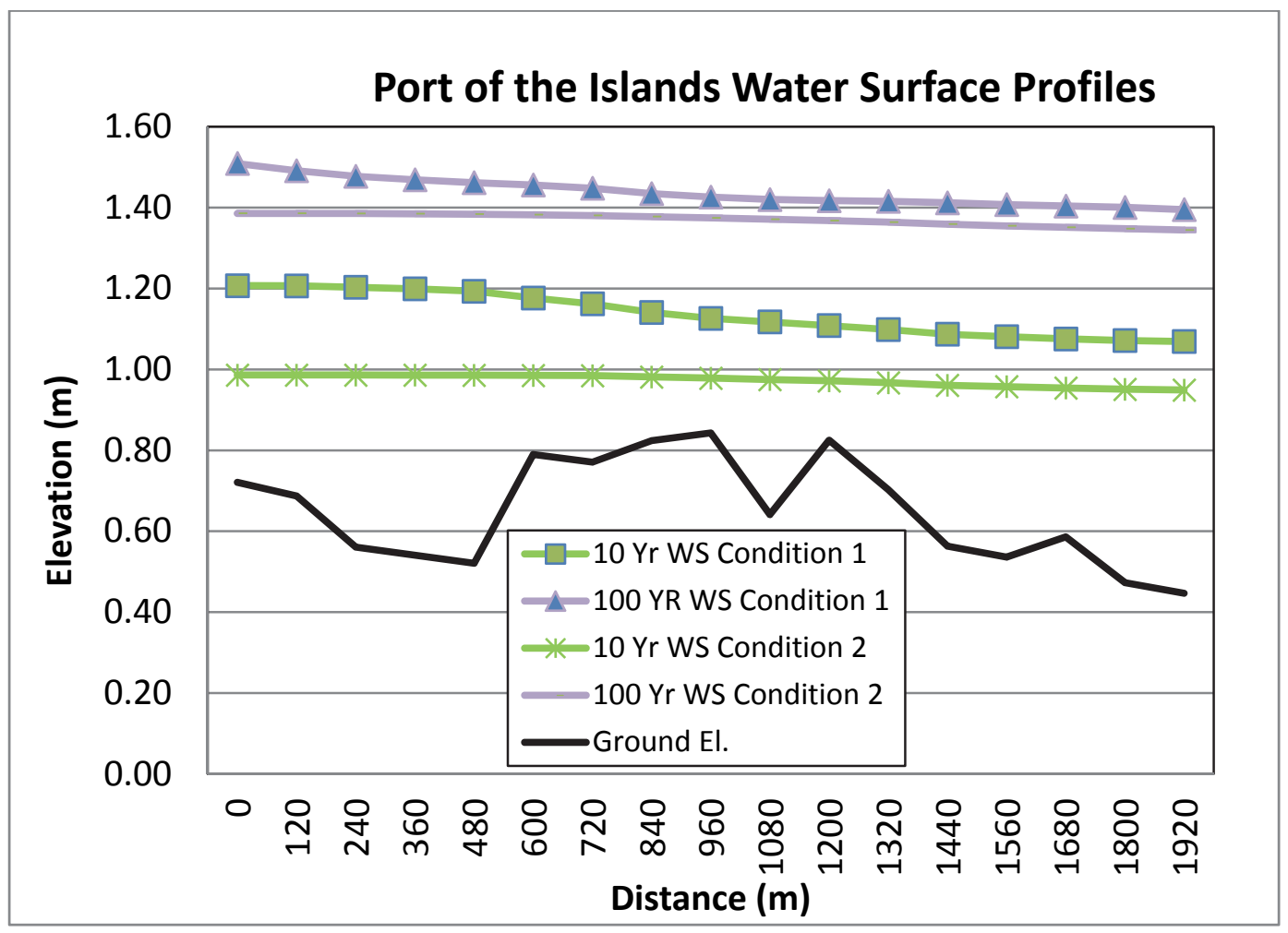


Figure 17. Cell-by-cell difference of maximum flood extent for the Private Lands T2 model. Western extent of the protective tie-back levee system as proposed in the PIR and as recommended in this study also shown.

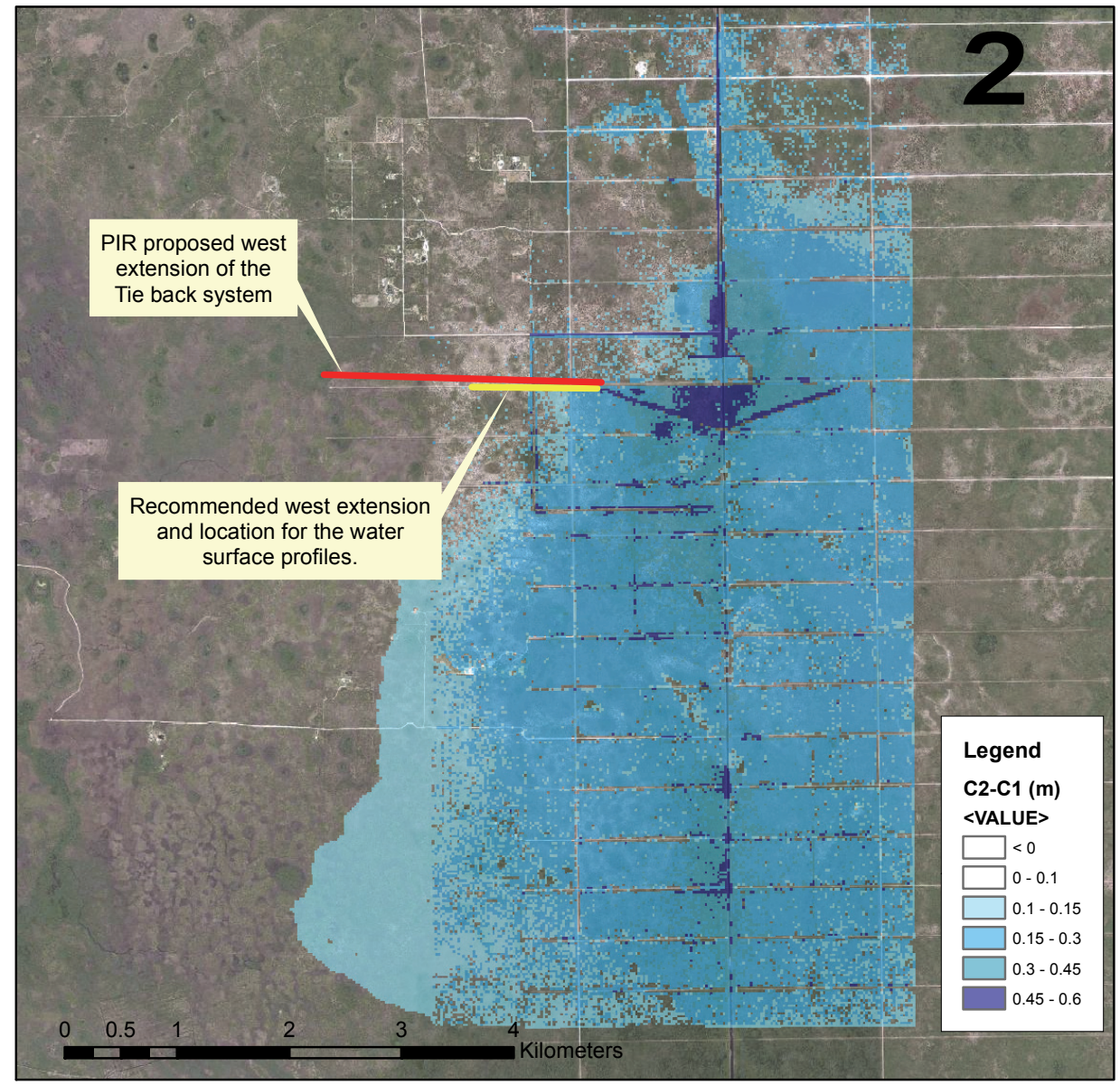

A water surface profile just south, along the alignment of the western portion of the tie-back levee system, shows that one of the reasons why the water levels do not increase in $\mathrm{C} 2$ relative to $\mathrm{C} 1$ near the private lands areas is due to the existence of a spoil mound located approximately 540 m east from the western end of the system. This spoil mound runs approximately $1000 \mathrm{~m}$ south and prevents water from the spreader berm from flanking the proposed levee where it could reach the Private Lands area. The resolution selected for these T2 models captured all these important details allowing for a refinement of the protective feature design as originally conceptualized in the PIR.

The cell-by-cell maximum flood extent difference grid for the 6Ls T2 model is shown in Figure 19. Due to the way in which water is spread over the landscape by the proposed restoration features (i.e., the Miller pump station and spreader berm system), the flooding extent in areas just 
outside the 6Ls farm are shown to increase in $\mathrm{C} 2$ relative to $\mathrm{C} 1$. The residual flooding east of the proposed 6Ls protective feature varies from $0.15 \mathrm{~m}$ east of the farms to $1.0 \mathrm{~m}$ in areas just south of the restoration features. A water surface profile (Figure 20) along the proposed feature for the 10-year and 100-year storm event frequencies also validates the results in Figure 19. The proposed embankment is therefore necessary to protect the $6 \mathrm{Ls}$ farms from flooding. Additional refinement of flood control features for this area may be needed to alleviate backwater effects or seepage into the $6 \mathrm{Ls}$.

Based on the maximum water levels, the Private Lands levee was modified as noted, and the POI levee is not being constructed. These project modifications result in approximately $\$ 40$ million (U.S. dollars) savings in project construction costs without a reduction in flood protection.

Figure 18. Water surface profiles along the western portion of the proposed tie-back levee system (see Figure 17 for profile locations).

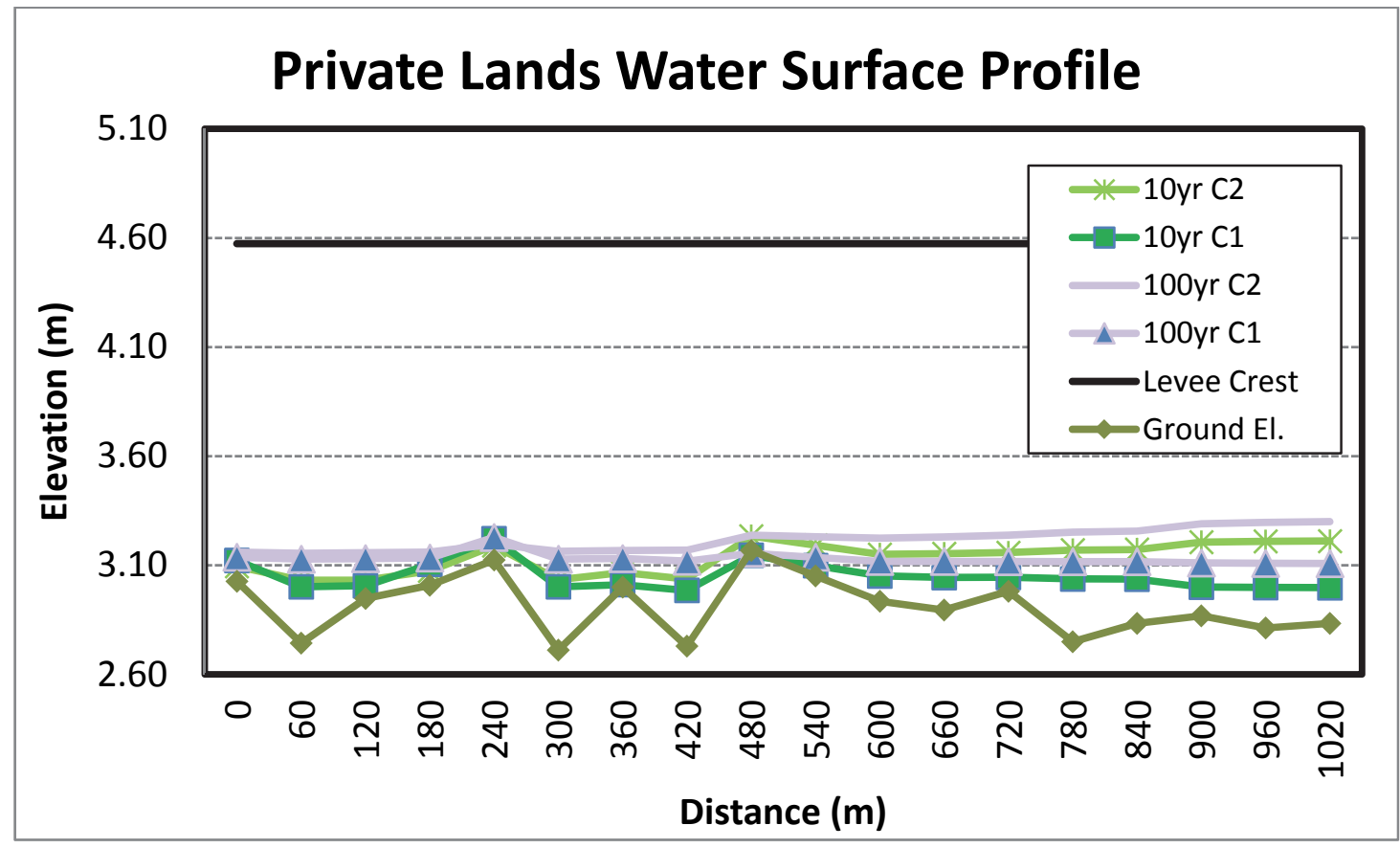


Figure 19. Cell-by-cell difference of the maximum flood extent between $\mathrm{C} 2$ and $\mathrm{C} 1$ in the 6 Ls T2 model.

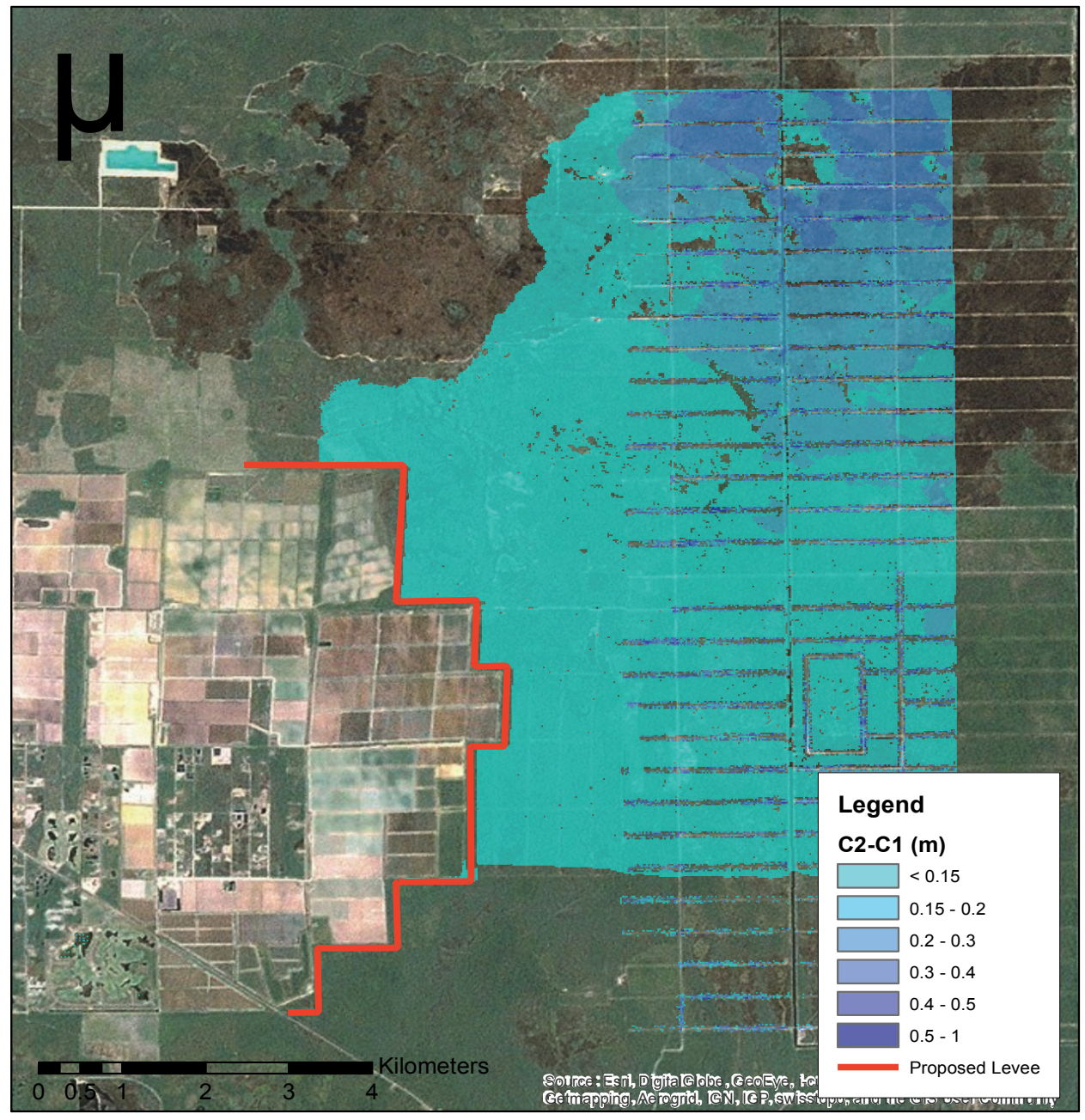


Figure 20. Water surface profiles along the proposed $6 \mathrm{Ls}$ protective levee. Profile starts at the northern end of the feature and ends at the intersection of the feature with U.S. Hwy 41.

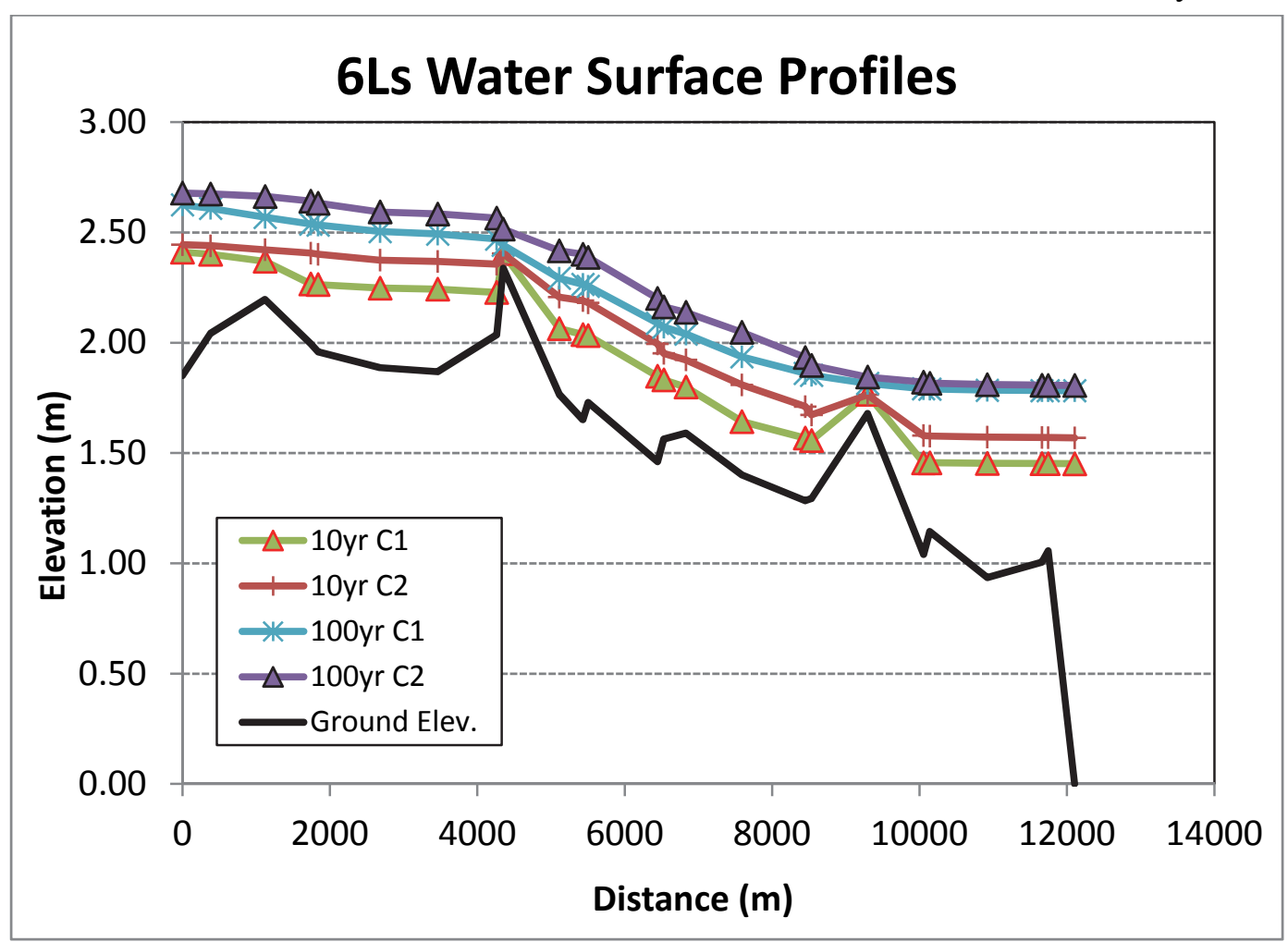




\section{Summary}

The GSSHA hydrologic model was applied to execute a multitiered, levelof-service flood study analysis on the existing PSRP and multiple idealizations of the preferred alternative for the flood protection features. The GSSHA models were built from existing spatial data and design documents. The models included a number of hydraulic structures, including canals, weirs, roads, levees, spreader canals, and pumps. The simulation of flows through embankments on the overland flow computational domain was facilitated by the development of overland hydraulic structures feature in GSSHA that allows flow to be passed from one overland flow grid cell to the next based on rating curves of depth or difference in stage versus flow. The model also utilized a new capability in the GSSHA model to derive boundary conditions for inset models and boundary conditions from the coarser T1 model to drive the finerresolution T2 models. Initial model parameters were derived from previous large-scale coarser hydrodynamic models used in the analysis to select the preferred alternative. The models were calibrated to existing flow and stage data in the canals and overland flow domains. Parameters specified as adjustable as part of the $\mathrm{T} 1 \mathrm{C} 1$ computer-based model calibration included not only model process related parameters but also parameters related to model configuration, input precipitation forcing, and adjustment of the base rating curve values that controlled the flow through the numerous bridge crossings along U.S. Hwy 41. Hence, the postcalibration model predictive uncertainty analysis included these elements in the quantification of the uncertainty associated with specific stage predictions selected to be analyzed with each project alternative.

One of two tractable methodologies for postcalibration model predictive uncertainty analysis was used with each of the PSRP GSSHA models representing project alternatives. Employment of either of these two analysis methods enabled quantification, at the $95 \%$ confidence level, of the maximum simulated stage at specific predetermined locations within the computational domains of the models representing the proposed project condition. All of the GSSHA models developed to characterize project alternatives were forced with the 5-day, 100-year design storm. Nonlinear postcalibration predictive uncertainty analysis was employed with the T1 project alternatives. A linear uncertainty analysis was 
employed to quantify the uncertainty associated with predictions from the T2 project alternatives, primarily due to project resource limitations. The results from these analyses supported risk-based hydrologic design of PSRP protection features. The hydrologic models and analysis demonstrated that based on maximum flood stage alone, some of these features were either unnecessary or overdesigned with respect to the original design selected in the tentatively selected plan. Suggested modifications could result in approximately $\$ 40$ million savings in construction costs. As this study focused on maximum flood stage alone, any concerns about flooding duration and possible backwater or seepage effects would need to be addressed with additional analysis.

This report and the software GSSHA are products of CHL. For more information about GSSHA, contact Natalie Elwart, Hydrologic Systems Branch, Coastal and Hydraulics Laboratory, U.S. Army Engineer Research and Development Center, 3909 Halls Ferry Road, Vicksburg, MS 391806199. Information on GSSHA can also be found on the GSSHA wiki at http://gsshawiki.com. 


\section{References}

Cooley, R. L., and A. V. Vecchia. 1987. Calculation of nonlinear confidence and prediction intervals for ground-water flow models. Water Resour. Bull. 23(4):581-599.

Doherty, J. 2004. PEST: Model independent parameter estimation. Fifth edition of user manual. Brisbane, Australia: Watermark Numerical Computing.

Downer, C. W., F. L. Ogden, J. Neidzialek, and S. Liu, 2005. GSSHA: A model for simulating diverse streamflow generating processes. Watershed Models, Chapter 6, V. P. Singh and D. Frevert. Boca Raton: CRC Press.

Skahill, B., J. Baggett, S. Frankenstein, and C. W. Downer. 2009. More efficient PEST compatible model independent model calibration. Environmental Modelling \& Software 24(4):517-529.

Skahill, B. E., C. W. Downer, and J. S. Baggett. 2012. A practical guide to calibration of a GSSHA hydrologic model using ERDC automated model calibration softwareefficient local search. ERDC/CHL TR-12-3. Vicksburg, MS: U.S. Army Engineer Research and Development Center.

U.S. Army Corps of Engineers, Jacksonville District (USACE, SAJ). 2004. Picayune Strand Restoration Project (formerly known as Southern Golden Gate Estates) Collier County, FL: Final integrated project implementation report and environmental impact statement, Jacksonville, FL, USACE SAJ. Jacksonville, FL: U.S. Army Corps of Engineers, Jacksonville District, South Florida Water Management District.

Vecchia, A. V., and Cooley, R. L. 1987. Simultaneous confidence and prediction intervals for nonlinear regression models with application to a ground water flow model. Water Resour. Res. 23(7):1237-1250. 
The public reporting burden for this collection of information is estimated to average 1 hour per response, including the time for reviewing instructions, searching existing data sources, gathering and maintaining the data needed, and completing and reviewing the collection of information. Send comments regarding this burden estimate or any other aspect of this collection of information, including suggestions for reducing the burden, to Department of Defense, Washington Headquarters Services, Directorate for Information Operations and Reports (0704-0188), 1215 Jefferson Davis Highway, Suite 1204, Arlington, VA 22202-4302. Respondents should be aware that notwithstanding any other provision of law, no person shall be subject to any penalty for failing to comply with a collection of information if it does not display a currently valid OMB control number. PLEASE DO NOT RETURN YOUR FORM TO THE ABOVE ADDRESS.

\begin{tabular}{l|l|l}
\hline 1. REPORT DATE & 2. REPORT TYPE & 3. DATES COVERED (From - To) \\
August 2016 & Technical Report & $\mathbf{2 0 1 3 - 2 0 1 6}$
\end{tabular}

\section{TITLE AND SUBTITLE}

Gridded Surface Subsurface Hydrologic Analysis Modeling for Analysis of Flood

Design Features at the Picayune Strand Restoration Project

5a. CONTRACT NUMBER

5b. GRANT NUMBER

\section{5c. PROGRAM ELEMENT NUMBER}

\section{AUTHOR(S)}

Charles W. Downer, Brian E. Skahill, Nawa Pradhan, and Aaron R. Byrd, Jaime A. Graulau-Santiago, and David M. Weston

\section{PERFORMING ORGANIZATION NAME(S) AND ADDRESS(ES)}

Coastal and Hydraulics Laboratory U.S. Army Engineer Research and Development Center 3909 Halls Ferry Road Vicksburg, MS 39180-6199;

Hydraulics and Hydrology Branch Jacksonville District U.S. Army Corps of Engineers 701 San Marcus Blvd Jacksonville, FL 32207

9. SPONSORING/MONITORING AGENCY NAME(S) AND ADDRESS(ES)

U.S. Army Corps of Engineers, Jacksonville District

701 San Marcus Blvd

Jacksonville, FL 32207

\section{5d. PROJECT NUMBER}

\section{3}

5e. TASK NUMBER

\section{5f. WORK UNIT NUMBER}

8GLOD0

\section{PERFORMING ORGANIZATION REPORT NUMBER}

ERDC/CHL TR-16-14

\section{SPONSOR/MONITOR'S ACRONYM(S) USACE SAJ}

11. SPONSOR/MONITOR'S REPORT NUMBER(S)

\section{DISTRIBUTION/AVAILABILITY STATEMENT}

Approved for public release; distribution is unlimited.

\section{SUPPLEMENTARY NOTES}

\section{ABSTRACT}

The Picayune Strand Restoration Project is one of many components of the Comprehensive Everglades Restoration Project (CERP) intended to restore nearly 700 hectares of a failed residential development in southwestern Collier County, FL, to its predevelopment wetland conditions. A detailed analysis was performed to derive a restoration plan that will achieve this goal. As required by the Water Resources Development Act (WRDA) 2000, the U.S. Army Corps of Engineers (USACE) is required to ensure that no component of CERP results in an effective taking of land by adversely impacting the level of flood protection of adjacent landowners. To ensure the current level of flood protection is maintained, a hydrologic model was developed to assess the potential for flooding and to refine the proposed flood mitigation features. The USACE physically based Gridded Surface Subsurface Hydrologic Analysis (GSSHA) model was selected for this effort. The GSSHA model simulates fully coupled rainfall distribution, extraction, retention, overland flow, and one-dimensional channel flow. Models of varying resolution were developed from existing and proposed design data and were initially populated with parameter values from a previous hydrodynamic modeling effort. Parameters were then tuned to observed stage and flow data using the Secant Levenberg-Marquardt method, a nonlinear least squares minimization computer-based local search method. The calibrated model is capable of reproducing canal flows, canal stages, and overland stages with very high Nash Sutcliffe Forecast Efficiencies, generally 0.9 or higher. Subsequent uncertainty analysis allowed water stages to be estimated with $95 \%$ certainty. Modeling and uncertainty analysis results allowed for refinement of the proposed flood mitigation features. The hydrologic models and analysis demonstrated that some of the features in the original plan were either unnecessary or overdesigned and could be modified or eliminated, resulting in $\$ 40 \mathrm{M}$ in flood control feature construction cost savings.

\section{SUBJECT TERMS}

Flood control, Flooding, Hydraulics, Hydraulic simulation, Hydrology, Hydrologic simulation, Modeling

\section{SECURITY CLASSIFICATION OF:}

a. REPORT Unclassified b. ABSTRACT c. Unclassified
17. LIMITATION OF ABSTRACT

THIS

Unclassified
18. NUMBER OF PAGES

51

\section{9a. NAME OF RESPONSIBLE PERSON Charles W. Downer}

19b. TELEPHONE NUMBER (Include area code) 5616822922 